\title{
Reassessment of the taxonomic status of Pseudopaludicola parnaiba (Anura, Leptodactylidae, Leiuperinae), with the description of a new cryptic species from the Brazilian Cerrado
}

\author{
Felipe Silva de ANDRADE ${ }^{1, *}$, Isabelle Aquemi HAGA ${ }^{2}$, Mariana Lúcio LYRA ${ }^{3}$, \\ Thiago Ribeiro de CARVALHO ${ }^{4}$, Célio Fernando Baptista HADDAD ${ }^{5}$, \\ Ariovaldo Antonio GIARETTA ${ }^{6} \&$ Luís Felipe TOLEDO ${ }^{7}$ \\ ${ }^{1,7}$ Laboratório de História Natural de Anfíbios Brasileiros (LaHNAB), \\ Departamento de Biologia Animal, Instituto de Biologia, \\ Universidade Estadual de Campinas (UNICAMP), Campinas, São Paulo, Brazil. \\ ${ }_{1,2,6}$ Laboratório de Taxonomia e Sistemática de Anuros Neotropicais (LTSAN), \\ Instituto de Ciências Exatas e Naturais do Pontal (ICENP), \\ Universidade Federal de Uberlândia (UFU), Ituiutaba, Minas Gerais, Brazil. \\ ${ }^{1}$ Programa de Pós-Graduação em Biologia Animal, Instituto de Biologia, \\ Universidade Estadual de Campinas (UNICAMP), Campinas, São Paulo, Brazil. \\ 3,4,5 Laboratório de Herpetologia, Departamento de Biodiversidade e Centro de Aquicultura \\ (CAUNESP), Instituto de Biociências, Universidade Estadual Paulista (UNESP), \\ Rio Claro, São Paulo, Brazil. \\ *Corresponding author: felipe andrade@ymail.com \\ 2Email: hagaisabelle@gmail.com \\ ${ }^{3}$ Email: marillyra@gmail.com \\ ${ }^{4}$ Email: thiago decarvalho@yahoo.com.br \\ ${ }^{5}$ Email: haddad1000@gmail.com \\ ${ }^{6}$ Email: aagiaretta@gmail.com \\ ${ }^{7}$ Email: toledosapo@gmail.com

\footnotetext{
${ }^{1}$ urn:1sid:zoobank.org:author:A6B5147E-158C-459C-97A7-B4E7ADE3DB23

${ }^{2}$ urn:Isid:zoobank.org:author:10EA92D6-7C2E-4141-A912-6E45B4EDF321

${ }^{3}$ urn:lsid:zoobank.org:author:7AD8365F-7BD9-4C37-9C41-8A0F03766E7C

${ }^{4}$ urn:lsid:zoobank.org:author:27C6C8C4-5CC0-4102-92D2-A692880886A5

${ }^{5}$ urn:lsid:zoobank.org:author:DCB4C25F-987D-402C-855B-E9CDDD7CDD08

${ }^{6}$ urn:lsid:zoobank.org:author:3A195123-AD86-42EC-8D18-756EC8BA6AB0

${ }^{7}$ urn:lsid:zoobank.org:author:2430A30A-DB39-4C75-9508-F9489557A223
}

\begin{abstract}
The Neotropical frog genus Pseudopaludicola includes 25 species distributed throughout South America. Herein we review the taxonomic status of $P$. parnaiba relative to $P$. canga and the specific identity of the population treated in previous studies as Pseudopaludicola sp. 3 from Barreirinhas in the Brazilian state of Maranhão. The lack of differentiation in advertisement call, morphology, and mitochondrial markers from topotypes and different populations rejects the status of P. parnaiba and Pseudopaludicola sp. 3 from Barreirinhas as distinct species. For these reasons, we suggest to formally
\end{abstract}


consider $P$. parnaiba as a junior synonym of $P$. canga. We also found that a population previously reported as P. facureae from central Brazil (Palmeiras de Goiás, Goiás) corresponds to a cryptic species that we describe here as a new species. Lastly, we provide for the first time the phylogenetic positions of P. giarettai, P. llanera and P. pusilla.

Keywords. Integrative taxonomy, Pseudopaludicola canga, mitochondrial DNA, morphologically cryptic species.

Andrade F.S., Haga I.A., Lyra M.L., Carvalho T.R., Haddad C.F.B, Giaretta A.A. \& Toledo L.F. 2020. Reassessment of the taxonomic status of Pseudopaludicola parnaiba (Anura, Leptodactylidae, Leiuperinae), with the description of a new cryptic species from the Brazilian Cerrado. European Journal of Taxonomy 679: 1-36. https://doi.org/10.5852/ejt.2020.679

\section{Introduction}

Cerrado is the largest savanna formation in South America and is among the most threatened biodiversity hotspots on Earth (Myers et al. 2000), mainly due to habitat loss caused by agribusiness expansion, infrastructure development and limited conservation incentives (Strassburg et al. 2017). In the few last decades, the knowledge on anuran species richness of the Cerrado has expanded increasingly fast, indicating that species composition in the region needs to be urgently documented given the intensive anthropogenic activities developed in the region (Valdujo et al. 2013; Strassburg et al. 2017). The increase in species richness is partly due to the recognition of cryptic species in this formation (e.g., Vaz-Silva \& Maciel 2011; Haga et al. 2017). Fišer et al. (2018) highlighted the importance of research efforts for fully integrating cryptic species into biodiversity science, thereby fostering a better understanding of the heterogeneous role of speciation in biodiversity pattern and process. Integrative taxonomy can notably improve the knowledge of frog diversity through species descriptions and delimitation, especially when dealing with morphologically cryptic species groups, recurrently reported for the frog genus Pseudopaludicola Miranda-Ribeiro, 1926 (e.g., Andrade et al. 2016, 2018a, 2018b, 2019; Pansonato et al. 2016; Cardozo et al. 2018).

The genus Pseudopaludicola includes 25 species (Frost 2020) that occur throughout most of South America (Lynch 1989). Pseudopaludicola is a monophyletic genus supported by the presence of a hypertrophied antebrachial tubercle (Lynch 1989) and some osteological features (Lobo 1995), as well as by molecular evidence based on mitochondrial DNA (Veiga-Menoncello et al. 2014). Veiga-Menoncello et al. (2014) indicated a clade including three nominal species, P. canga Giaretta \& Kokubum, 2003, P. facureae Andrade \& Carvalho, 2013, P. atragula Pansonato, Mudrek, Veiga-Menoncello, RossaFeres, Martins \& Strüssmann, 2014, and a putative species, Pseudopaludicola sp. 3 (aff. canga) from Barreirinhas, MA, northern Brazil. Since then, the putative species has been treated as a species yet to be described (Veiga-Menoncello et al. 2014; Pansonato et al. 2014a; Andrade et al. 2016, 2018a, 2018b, 2019; Cardozo et al. 2018).

Pseudopaludicola parnaiba Roberto, Cardozo \& Ávila, 2013 is known only from its type locality, the municipality of Ribeiro Gonçalves, PI, Brazil (Roberto et al. 2013). This species is supposedly closely related to $P$. canga, $P$. facureae and $P$. atragula, but, to date, there is no molecular evidence available for a phylogenetic assessment. Based on acoustic and morphological traits, Carvalho et al. (2015a) stated that this species could not be distinguished from $P$. canga, and suggested that an integrative reassessment of the taxonomic status of P. parnaiba in relation to P. canga was necessary. Pseudopaludicola giarettai Carvalho, 2012 is a well-characterized species, based on acoustic and morphological data (Carvalho 2012; Carvalho et al. 2015b). However, the phylogenetic position of the species remains to be tested (Andrade et al. 2018a, 2018b, 2019). 
ANDRADE F.S. et al., Taxonomic status of P. parnaiba and a new congeneric species

Carvalho et al. (2015a) also characterized the call of a population of Pseudopaludicola from the municipality of Palmeiras de Goiás, GO, Brazil, with the same trilled advertisement call pattern as $P$. facureae. Herein we combined acoustical, morphological and genetic evidence to (1) review the taxonomic status of $P$. parnaiba based on novel information from topotypes and additional populations of P. canga; (2) evaluate the specific identities of the population treated as Pseudopaludicola sp. 3 (sensu Veiga-Menoncello et al. 2014) and of the population from Palmeiras de Goiás; and (3) assess for the first time the phylogenetic positions of P. giarettai, P. pusilla (Ruthven, 1916) and P. llanera Lynch, 1989, providing the most complete mitochondrial phylogeny of the genus so far, with 21 species sampled. Our results revealed a cryptic species closely related to $P$. atragula and $P$. facureae, which we describe here as new.

\section{Material and methods}

\section{Reference specimens}

Specimens of the type series of the new species were collected and recorded in Palmeiras de Goiás $\left(16^{\circ} 46^{\prime} 59^{\prime \prime} \mathrm{S}, 49^{\circ} 52^{\prime 2} 2^{\prime \prime} \mathrm{W} ; 652 \mathrm{~m}\right.$ above sea level (a.s.1.); datum = WGS84; Fig. 1), GO, Brazil. Type specimens are deposited in the amphibian collection of Museu de Zoologia "Adão José Cardoso" (ZUEC) of the Universidade Estadual de Campinas (UNICAMP), Campinas, SP, and in the Collection of frogs of the Museu de Biodiversidade do Cerrado (AAG-UFU), Universidade Federal de Uberlândia (UFU), Uberlândia, MG, both in Brazil.

We collected and recorded specimens of P. parnaiba at its type locality $\left(7^{\circ} 35^{\prime} 42.19^{\prime \prime} \mathrm{S}, 45^{\circ} 20^{\prime} 36.66^{\prime \prime} \mathrm{W}\right.$, $203 \mathrm{~m}$ a.s.1.; datum $=$ WGS84) on 10 February 2019. Also, we collected and recorded individuals at the locality of the three sequenced specimens (ZUEC 13858-60) of Pseudopaludicola sp. 3 (VeigaMenoncello et al. 2014), in the Tabocas Village, municipality of Barreirinhas, MA, Brazil ( $3^{\circ} 0^{\prime} 28.96^{\prime \prime} \mathrm{S}$, $43^{\circ} 8^{\prime} 29.56^{\prime \prime} \mathrm{W}, 43 \mathrm{~m}$ a.s.l.; datum = WGS84) on 13 February 2019. In addition, we found another population of Pseudopaludicola sp. 3 about $20 \mathrm{~km}$ north from Tabocas Village, in the municipality of

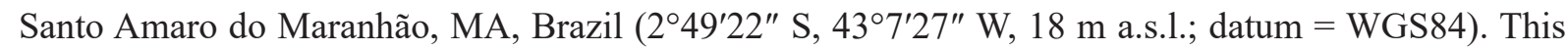
last population was assigned to Pseudopaludicola sp. 3 based on its geographical proximity (see Fig. 1), besides the morphological and acoustic similarities.

Specimens were collected under authorization number \#30059-12 issued by SISBio / ICMBio (Instituto Chico Mendes de Conservação da Biodiversidade). According to current legislation, the access to the National System for the Management of Genetic Heritage and Associated Traditional Knowledge was registered (SISGen \#A2FCFCC). Individuals were euthanized by applying 5\% lidocaine to the skin. After that, we collected muscle tissue for genetic analyses, fixed specimens in $10 \%$ formalin and transferred them to $70 \%$ ethanol for permanent storage. The new species hypothesis is in accordance to the General Lineage Concept, which treats species as separately evolving metapopulation lineages (de Queiroz 1998, 2007).

\section{Morphometry}

We measured 11 adult males and five adult females (type series) of the new species under a stereo microscope Zeiss Stemi 2000 coupled to an ocular micrometer; except snout-vent length which was taken with a Mitutoyo Absolute digital caliper (to the nearest $0.1 \mathrm{~mm}$ ) under a stereo microscope. Twelve morphometric traits were measured following Watters et al. (2016): snout-vent length, head length, head width, eye diameter, interorbital distance, eye-nostril distance, snout length, internarial distance, hand length, thigh length, tibia length and foot length. Tarsus length was measured following Heyer et al. (1990). Terminal phalanges or expanded toe tips were verified by clearing and staining. These procedures were conducted following the protocols of Taylor \& Van Dyke (1985). Shape of the 
snout in dorsal and lateral views follows Heyer et al. (1990). Further details on examined specimens are in Appendix 1.

\section{Bioacoustics}

We recorded vocalizations with two digital recorders at sampling rate of $44.1 \mathrm{kHz}$ and a sample size of 16 bits: Marantz PMD 661MKII (Marantz, Japan) and M-audio Microtrack II (M-audio, USA), both with a Sennheiser ME66/K6 or ME 67/K6 directional microphones (Sennheiser electronic GmbH \& Co. KG, Germany). Directional microphones were positioned about $1.5 \mathrm{~m}$ from the calling male. We analyzed calls with Raven Pro 1.5, 64-bit version (Bioacoustics Research Program 2014) with the following settings: window type $=$ Hann, window size $=256$ samples, $3 \mathrm{~dB}$ filter bandwidth $=248 \mathrm{~Hz}$,

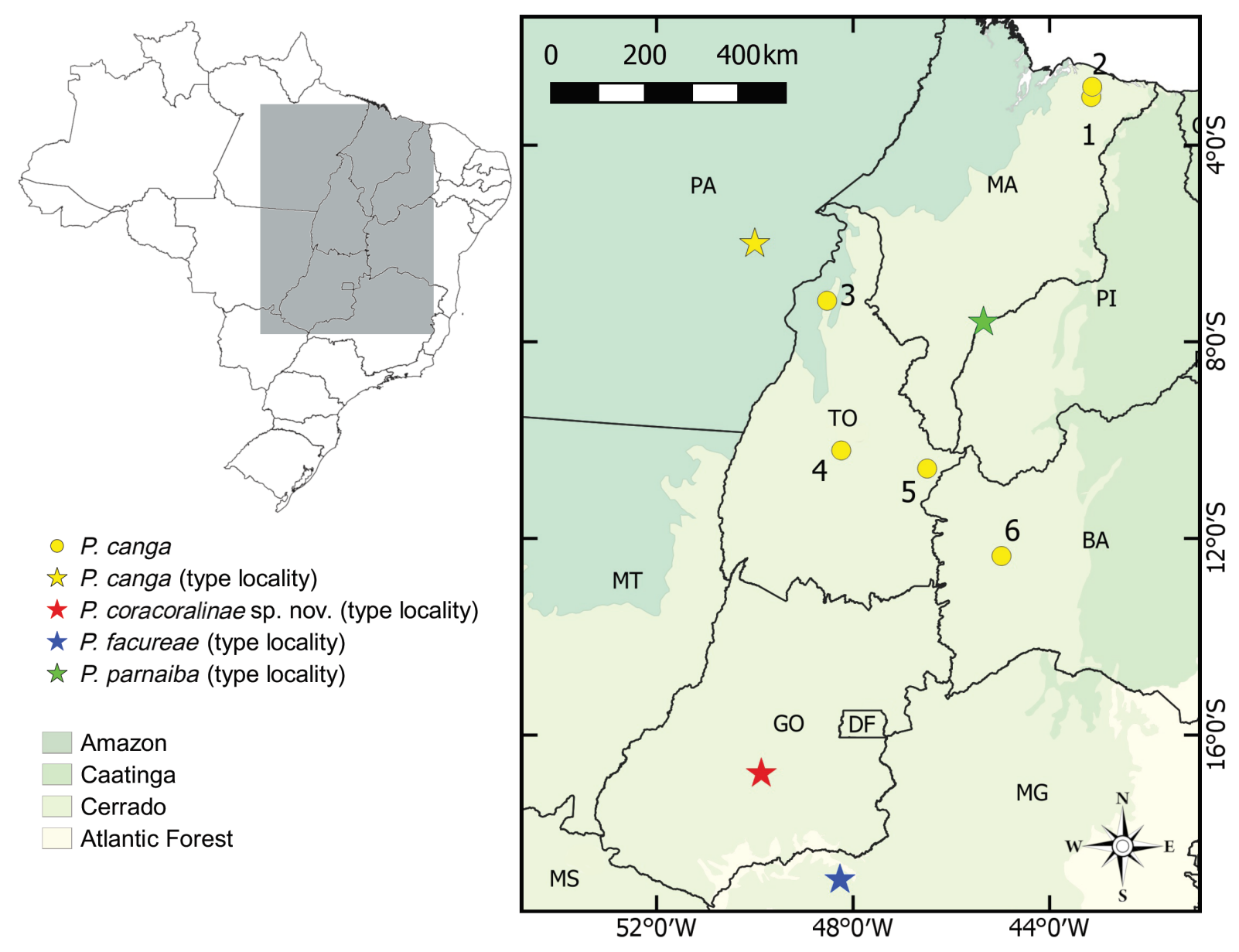

Fig. 1. Partial map of South America showing the Brazilian domains and samples of the species included in our molecular, morphological and acoustic comparisons. The type localities of the species are indicated with stars: Pseudopaludicola coracoralinae sp. nov. in Palmeiras de Goiás, GO (red star), P. facureae Andrade \& Carvalho, 2013 in Uberlândia, MG (blue star), P. canga Giaretta \& Kokubum, 2003 in Marabá, PA (yellow star) and P. parnaiba Roberto, Cardozo \& Ávila, 2013 in Ribeiro Gonçalves, PI (green star). Municipalities: 1 = Barreirinhas (MA); $2=$ Santo Amaro do Maranhão (MA); $3=$ Aragominas (TO); 4 = Palmas (TO); 5 = Mateiros (TO); 6 = São Desidério (BA). Veiga-Menoncello et al. (2014) first noticed a taxonomic unit which they called as Pseudopaludicola sp. 3 from Barreirinhas, MA. Since then it has been treated as a species not yet formally described. It is represented here as P. canga from the localities 1 and 2 . 
ANDRADE F.S. et al., Taxonomic status of P. parnaiba and a new congeneric species

brightness $=50 \%$, contrast $=50 \%$, overlap $=85 \%$ (locked), DFT size $=1024$ samples (locked) and grid spacing (spectral resolution) $=43.1 \mathrm{~Hz}$. Raven obtained the peaks of dominant frequency through its "Peak Frequency (Hz)" function. The frequency values with 5 and $95 \%$ of call energy were obtained by "Frequency 5\%" and "Frequency 95\%" functions, and were considered as the minimum and maximum frequencies $(\mathrm{Hz})$, respectively. We assessed frequency modulation through the " $1{ }^{\text {st }}$ Quartile Frequency" and " 3 rd Quartile Frequency" functions; these Raven functions provide the frequencies that divide the selection into two frequency intervals containing 25 and $75 \%$ of the energy in the selection, respectively (Charif et al. 2010). We generated call figures using the Seewave ver. 1.6 package (Sueur et al. 2008) in $\mathrm{R}$ ver. 3.5.3 64-bit (R Core Team 2019). Seewave settings were: Hanning window, 90\% overlap and 256 points resolution (FFT). We also assessed the between-male call variation through the coefficients of variation $(\mathrm{CV}=(\mathrm{SD} /$ mean $) \times 100)$. We considered only the stereotyped non-pulsed notes to calculate the CV values of the species, not the introductory notes. Gerhardt (1991) reported that between-male coefficients of variation of static acoustic properties were less than $11 \%$, whereas coefficients of variation of dynamic properties exceeded $15 \%$.

Temporal traits were measured on oscillograms and the spectral traits were measured on spectrograms. Details for acoustic terminology employed here for the species are available in Supplementary file 1. Pulse terminology follows Magalhães et al. (2014); note and call terminologies follow Köhler et al. (2017). We calculated means and standard deviations considering mean values of individual males, whereas the range (variation) encompasses the minimum and the maximum values for all call samples. For multivariate analyses, we considered only the stereotyped notes, not the introductory notes, because the introductory notes are very irregular and have no clear pattern. Sound files are deposited in Arquivo Sonoro da Coleção de Anuros da Universidade Federal de Uberlândia at UFU and in Fonoteca Neotropical Jacques Vielliard (FNJV) at UNICAMP, both in Brazil.

We recorded the vocalizations of 18 males of the new species in the municipality of Palmeiras de Goiás, GO. Further details of all the analyzed sound files of the new species are given in Appendix 2. We reanalyzed the recordings of 10 topotypical males of the original description of $P$. facureae (Andrade \& Carvalho 2013) for comparisons with the new species. Additionally, we analyzed nine topotypical males of $P$. facureae that we recorded on 15 March 2019 at Jardim Karaíba neighborhood, municipality of Uberlândia, MG, Brazil. The recordings of four of these males of $P$. facureae are deposited at FNJV (FNJV 40312-5) and the other five are at Arquivo Sonoro da Coleção de Anuros (UFU).

We recorded and analyzed the vocalizations of 16 topotypical males of P. parnaiba (FNJV 40328-43). In order to maintain the reliability of acoustic comparisons with this species, as well as to guarantee the integrative approach, we used only acoustic data from males of populations from which we also have fragments of mitochondrial DNA. Therefore, we carried out our comparative analyzes based on calls from 12 males of Pseudopaludicola sp. 3 (FNJV 40316-27) of Veiga-Menoncello et al. (2014) from Barreirinhas and 17 males from Santo Amaro (FNJV 40344-60), both in MA, Brazil; three males of $P$. cf. canga from Aragominas, two males from Mateiros and two males from Palmas, all in TO, Brazil; and three topotypical males of $P$. canga from Marabá, PA, Brazil. Topotypical males of $P$. canga were recorded by Adão José Cardoso on July and August 1984 with an Uher analog tape recorder and an Uher M-538 microphone. Additionally, we analyzed recordings of trilled calls of the two males from the municipality of São Desidério, BA, Brazil. We did not include these last specimens in the multivariate analyses because we did not have their genetic information.

\section{Statistical analysis}

We sought for morphometric and acoustic discriminations among species by applying the function randomForest (RF) (randomForest ver. 4.6-14 package; Liaw \& Wiener 2002) which constructs many (e.g., 1000) classification trees using bootstrap samples of the data (each split using the best predictors 
among those randomly chosen at each node) then generating classifiers and aggregating results by voting to classes (further details in Liaw \& Wiener 2002). The function proximityPlot (rfPermute ver. 2.1.6 package; Archer 2018) creates a plot of RF proximity scores using multi-dimensional scaling. The direct or indirect packages for this discriminant analyses were run in $\mathrm{R}$ ver. 3.5.3 64-bit (R Core Team 2019).

For the morphometric multivariate analysis between new species and $P$. facureae, we used snout-vent length, head length, head width, eye diameter, eye-nostril distance, internarial distance, hand length, thigh length, tibia length and foot length. For the acoustic multivariate analysis and statistical tests, we used note duration, internote interval, number of notes per minute, number of notes per series, series duration, interseries interval, number of series per call, peak of dominant frequency, and minimum and maximum of dominant frequency. Acoustic traits were tested for statistical significance of differences between species through the "Exact Wilcoxon Mann Whitney Rank Sum Test", function wilcox_test of the package Coin (Resampling Statistics model; Hothorn et al. 2008) in R. We considered significance when $P \leq 0.05$.

\section{Sequence analyses and phylogenetic inferences}

For the taxonomic evaluations, we collected new tissue samples for specimens from Palmeiras de Goiás, GO; topotypes of P. parnaiba; specimens of $P$. canga from three different localities in TO; specimens of Pseudopaludicola sp. 3 of Veiga-Menoncello et al. (2014) from Barreirinhas and Santo Amaro do Maranhão, both in MA; and topotypes and other specimens of $P$. giarettai from Grande Sertão Veredas National Park, MG, Brazil (Appendix 3).

We extracted total DNA from newly collected samples using a standard ammonium acetate precipitation method (Maniatis et al. 1982; adapted by Lyra et al. 2017). We amplified a fragment of mitochondrial DNA including the partial sequences of 12S rRNA, tRNA-val and 16S rRNA genes (H1 fragment, $\sim 2450 \mathrm{bp}$; see Appendix 4 for primers used) for all species. PCR products were purified using enzymatic reaction and sent to Macrogen Inc. Republic of Korea, to be sequenced in an ABI 3730 automated DNA sequencer. New DNA sequences were edited for quality and assembled using Geneious ver. 11 (Biomatter) and submitted to GenBank (Appendix 3).

The new sequences were combined with the sequences available in GenBank for Pseudopaludicola spp. from previous works and 19 outgroups (Appendix 3), totalizing 94 samples. The H1 fragment was aligned using MAFFT ver. 7.25 using E-INS-I strategy (Katoh \& Standley 2013). We performed Maximum Likelihood (ML) analysis with RAXML ver. 8.2.12 (Stamatakis 2014), searching for the most likely tree with 1000 replicates and using the GTRCAT substitution model. We then estimated node support with 1000 non-parametric bootstrap replicates under the same model. Analyses were run in the CIPRES Science Gateway (Miller et al. 2010). We edited the most likely tree in FigTree ver. 1.4.2 (http://tree.bio.ed.ac.uk/software/figtree).

The maximum genetic distances within species and/or populations and minimum genetic distances between species were calculated for the 16S fragment flanked by primers $16 \mathrm{Sar}-\mathrm{L}$ and $16 \mathrm{Sbr}-\mathrm{H}$, since this fragment was available for all samples included in the analyses. Estimates were done using the package Spider in R ver. 3.6.1 (Brown et al. 2012; R Core Team 2019), uncorrected p-distances and the alignment obtained with MAFFT. Gaps and missing data were treated as pairwise deletions in uncorrected p-distances.

\section{Abbreviations of acoustic traits}

INI = internote interval

ISI $=$ interseries interval

MaxDF $=$ max. reached dominant frequency 


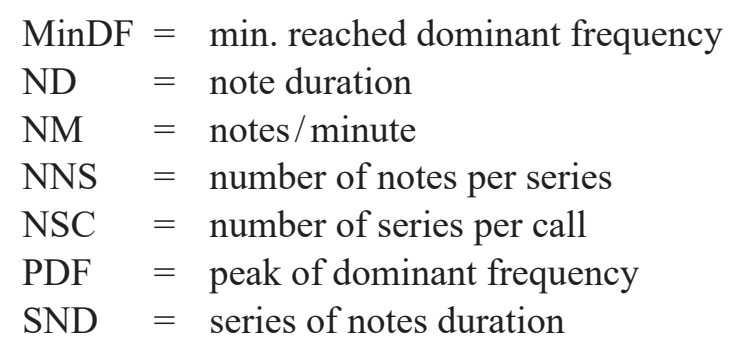

\section{Abbreviations of morphometric traits}

$\begin{array}{ll}\mathrm{ED} & =\text { eye diameter } \\ \mathrm{END} & =\text { eye-nostril distance } \\ \mathrm{FL} & =\text { foot length } \\ \mathrm{HAL} & =\text { hand length } \\ \mathrm{HL} & =\text { head length } \\ \mathrm{HW} & =\text { head width } \\ \mathrm{IND} & =\text { internarial distance } \\ \mathrm{IOD} & =\text { interorbital distance } \\ \mathrm{SL} & =\text { snout length } \\ \mathrm{SVL} & =\text { snout--vent length } \\ \mathrm{TAL} & =\text { tarsus length } \\ \mathrm{TBL} & =\text { tibia length } \\ \mathrm{TL} & =\text { thigh length }\end{array}$

\section{Repositories}

AAG-UFU $=$ Collection of frogs of the Museu de Biodiversidade do Cerrado, Universidade Federal de Uberlândia (UFU), Uberlândia, Minas Gerais, Brazil

ANDES-A $=$ Museo de Historia Natural ANDES at the Universidad de los Andes, Colombia

$\mathrm{CFBH}=$ Célio F.B. Haddad Collection, Departamento de Biodiversidade, Universidade Estadual Paulista, Campus de Rio Claro, São Paulo, Brazil

CFBH-T = Célio F.B. Haddad Tissues Collection, Departamento de Biodiversidade, Universidade Estadual Paulista, Campus de Rio Claro, São Paulo, Brazil

MACN $=$ Museo Argentino de Ciencias Naturales Bernardino Rivadavia, Buenos Aires, Argentina

MLP-DB $=$ Museo de La Plata, La Plata, Argentina

MNRJ $=$ Museu Nacional/Universidade Federal do Rio de Janeiro, Rio de Janeiro, Brazil

SMRP $\quad=$ Shirlei Maria Recco-Pimentel Collection, Departamento de Biologia Estrutural e Funcional, Universidade Estadual de Campinas, Campinas, São Paulo, Brazil

UFMG $=$ Amphibian Collection of the Universidade Federal de Minas Gerais (UFMG), Belo Horizonte, Minas Gerais, Brazil

UFU $\quad=$ Universidade Federal de Uberlândia, Brazil

FNJV $\quad=$ Fonoteca Neotropical Jacques Vielliard, Universidade Estadual de Campinas, São Paulo, Brazil

DZSRJP $=$ Amphibian Collection of the Departamento de Zoologia e Botânica, Universidade Estadual Paulista, São José do Rio Preto, São Paulo, Brazil

ZUEC = Museu de Zoologia “prof. Adão José Cardoso", Universidade Estadual de Campinas, Campinas, São Paulo, Brazil

ZUFMS $=$ Zoological collection (ZUFMS) of the Universidade Federal de Mato Grosso do Sul (UFMS), Campo Grande, Mato Grosso do Sul, Brazil 


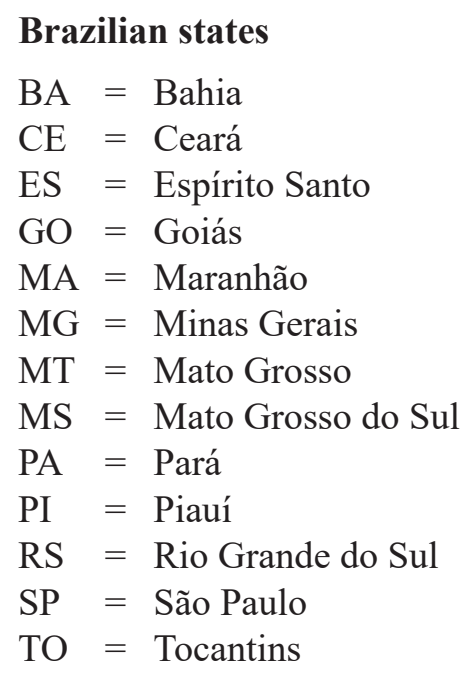

\section{Results}

\section{Taxonomic status of Pseudopaludicola parnaiba and Pseudopaludicola sp. 3 of Veiga-Menoncello et al. (2014) from Barreirinhas, state of Maranhão}

Based on acoustics traits, we were unable to discriminate topotypical males of P. parnaiba from those of Pseudopaludicola sp. 3 from Barreirinhas and Santo Amaro do Maranhão (Table 1). The RF multivariate approach applied to acoustic data indicated a broad overlap between these two partitions (Fig. 2), with a considerable classification error (Table 2). Moreover, the results were very similar when comparing both P. parnaiba and Pseudopaludicola sp. 3 with P. canga (topotypical and non-topotypical males from TO), with a broad overlap of these four partitions (Fig. 2). All three topotypes of $P$. canga were correctly classified, while the other three groupings had classification errors (Table 2). In contrast, the raw data of their variables overlapped with those of P. parnaiba, Pseudopaludicola sp. 3 and P. canga from TO (Table 1).

Furthermore, the specimens of Pseudopaludicola sp. 3 and P. parnaiba were nested together with specimens of $P$. canga from TO in the topology of the phylogenetic tree (Fig. 3). Based on the $16 \mathrm{~S}$ fragment, the minimum uncorrected p-distance was $0.21 \%$ between Pseudopaludicola sp. 3 and P. parnaiba, and $2.27 \%$ between Pseudopaludicola sp. 3 and $P$. canga from the type locality (Supplementary file 2). The genetic distance between $P$. parnaiba and $P$. canga from the type locality was $1.86 \%$ (Supplementary file 2 ).

In short, the acoustic and genetic evidence did not support a novel specific identity for Pseudopaludicola sp. 3 of Veiga-Menoncello et al. (2014). Also, the values of all traits of the analyzed calls of the two males from São Desidério, BA, overlapped with those described for $P$. canga in the present study (Table 1). Therefore, P. canga is the most suitable taxonomic identity for the populations of Pseudopaludicola sp. 3 of Veiga-Menoncello et al. (2014) and this one from São Desidério.

\section{Phylogenetic inference for Pseudopaludicola}

The final alignment used for phylogenetic inference contained $2499 \mathrm{bp}$, and the tree obtained (Fig. 3) recovered basically the same topologies and interspecific relationships inferred in previous analyses of Pseudopaludicola (Veiga-Menoncello et al. 2014; Andrade et al. 2016, 2018a, 2018b, 2019). The genus was recovered as monophyletic, composed of two major clades (Supplementary file 3). One major clade, identified as I $(2 \mathrm{n}=22)$ by Veiga-Menoncello et al. $(2014)$, included two subclades. One subclade is well-supported (Bootstrap Support, BS $=99$ ) and is composed of P. falcipes (Hensel, 1867), 
ANDRADE F.S. et al., Taxonomic status of P. parnaiba and a new congeneric species

Table 1. Advertisement call traits based on the recordings of topotypical males of Pseudopaludicola parnaiba Roberto, Cardozo \& Ávila, 2013 and P. canga Giaretta \& Kokubum, 2003; males of Pseudopaludicola sp. 3 from Barreirinhas and Santo Amaro do Maranhão; three males from Aragominas, two from Mateiros and other two from Palmas, all these seven are non-topotypical males of $P$. canga from TO; and additional non-topotypical males of P. canga from São Desidério, BA, Brazil. Values presented as mean \pm standard deviation (minimum-maximum). $\mathrm{n}=$ analyzed males (analyzed notes).

\begin{tabular}{|c|c|c|c|c|c|}
\hline & \multirow{2}{*}{$\begin{array}{l}\text { P. parnaiba } \\
\text { Topotypes }\end{array}$} & \multicolumn{3}{|c|}{ P. canga } & \multirow{2}{*}{$\begin{array}{l}\text { Pseudopaludicolo } \\
\text { sp. } 3\end{array}$} \\
\hline & & $\begin{array}{c}\text { Topotypes, } \\
\text { state of Pará }\end{array}$ & $\begin{array}{l}\text { State of } \\
\text { Tocantins }\end{array}$ & $\begin{array}{c}\text { São Desidério, } \\
\text { state of Bahia }\end{array}$ & \\
\hline Analyzed males (n) & 16 & 3 & 7 & 2 & 29 \\
\hline Analyzed notes (n) & 312 & 196 & 140 & 40 & 570 \\
\hline Call duration (s) & $\begin{array}{l}16.7 \pm 11.4 \\
(2.5-43.3)\end{array}$ & $\begin{array}{l}10.9 \pm 5.6 \\
(6.6-17.7)\end{array}$ & $\begin{array}{l}15.2 \pm 5.3 \\
(7.4-24.9)\end{array}$ & $\begin{array}{c}27.6 \pm 31.6 \\
(5.2-49.9)\end{array}$ & $\begin{array}{c}24.2 \pm 13.1 \\
(2.2-49.3)\end{array}$ \\
\hline $\begin{array}{l}\text { Series of notes } \\
\text { duration (s) }\end{array}$ & $\begin{array}{l}0.7 \pm 0.3 \\
(0.1-5.9)\end{array}$ & $\begin{array}{l}0.5 \pm 0.1 \\
(0.2-0.6)\end{array}$ & $\begin{array}{l}1.9 \pm 0.9 \\
(0.3-7.3)\end{array}$ & $\begin{array}{l}1.2 \pm 0.3 \\
(0.7-1.8)\end{array}$ & $\begin{array}{c}1.7 \pm 2.0 \\
(0.1-10.6)\end{array}$ \\
\hline Interseries interval (s) & $\begin{array}{l}0.7 \pm 0.1 \\
(0.2-2.2)\end{array}$ & $\begin{array}{l}2.0 \pm 0.5 \\
(0.6-6.6)\end{array}$ & $\begin{array}{l}0.9 \pm 0.3 \\
(0.4-2.1)\end{array}$ & $\begin{array}{l}1.2 \pm 0.0 \\
(0.9-1.4)\end{array}$ & $\begin{array}{l}0.5 \pm 0.2 \\
(0.2-1.7)\end{array}$ \\
\hline $\begin{array}{l}\text { Number of series per } \\
\text { call }\end{array}$ & $\begin{array}{l}12.9 \pm 7.3 \\
(3.0-30.0)\end{array}$ & $\begin{array}{l}4.7 \pm 1.5 \\
(3.0-8.0)\end{array}$ & $\begin{array}{c}8.0 \pm 4.8 \\
(4.0-17.0)\end{array}$ & $\begin{array}{l}11.0 \pm 11.3 \\
(3.0-19.0)\end{array}$ & $\begin{array}{l}18.9 \pm 10.7 \\
(4.0-37.0)\end{array}$ \\
\hline $\begin{array}{l}\text { Number of notes per } \\
\text { series }\end{array}$ & $\begin{array}{c}8.6 \pm 2.8 \\
(2.0-61.0)\end{array}$ & $\begin{array}{l}6.8 \pm 1.2 \\
(3.0-9.0)\end{array}$ & $\begin{array}{c}21.6 \pm 10.1 \\
(5.0-85.0)\end{array}$ & $\begin{array}{c}16.3 \pm 3.2 \\
(11.0-23.0)\end{array}$ & $\begin{array}{c}18.0 \pm 17.1 \\
(2.0-94.0)\end{array}$ \\
\hline Note duration (ms) & $\begin{array}{c}25 \pm 4 \\
(14-42)\end{array}$ & $\begin{array}{c}29 \pm 4 \\
(21-45)\end{array}$ & $\begin{array}{c}26 \pm 2 \\
(18-33)\end{array}$ & $\begin{array}{c}20 \pm 1 \\
(17-22)\end{array}$ & $\begin{array}{c}26 \pm 2 \\
(19-35)\end{array}$ \\
\hline Internote interval (ms) & $\begin{array}{c}56 \pm 11 \\
(29-110)\end{array}$ & $\begin{array}{c}48 \pm 7 \\
(36-73)\end{array}$ & $\begin{array}{c}61 \pm 6 \\
(45-118)\end{array}$ & $\begin{array}{c}56 \pm 8 \\
(45-69)\end{array}$ & $\begin{array}{c}66 \pm 14 \\
(27-152)\end{array}$ \\
\hline Notes / minute & $\begin{array}{c}843.2 \pm 154.4 \\
(557.1-1285.7)\end{array}$ & $\begin{array}{c}862.8 \pm 91.5 \\
(676.7-944.9)\end{array}$ & $\begin{array}{c}727.7 \pm 47.8 \\
(582.0-891.7)\end{array}$ & $\begin{array}{c}815.4 \pm 81.7 \\
(744.2-919.2)\end{array}$ & $\begin{array}{c}702.3 \pm 114.4 \\
(368.5-1097.9)\end{array}$ \\
\hline $\begin{array}{l}\text { Peak of dominant } \\
\text { frequency }(\mathrm{kHz})\end{array}$ & $\begin{array}{l}4.59 \pm 0.17 \\
(4.18-4.87)\end{array}$ & $\begin{array}{l}3.87 \pm 0.13 \\
(3.75-4.13)\end{array}$ & $\begin{array}{l}4.33 \pm 0.23 \\
(4.00-4.73)\end{array}$ & $\begin{array}{l}4.16 \pm 0.36 \\
(3.84-4.50)\end{array}$ & $\begin{array}{l}4.44 \pm 0.25 \\
(3.94-4.99)\end{array}$ \\
\hline $\begin{array}{l}\text { Min. reached dominant } \\
\text { frequency }(\mathrm{kHz})\end{array}$ & $\begin{array}{l}4.40 \pm 0.15 \\
(4.00-4.69)\end{array}$ & $\begin{array}{l}3.77 \pm 0.13 \\
(3.66-4.00)\end{array}$ & $\begin{array}{l}4.14 \pm 0.22 \\
(3.88-4.59)\end{array}$ & $\begin{array}{l}4.00 \pm 0.43 \\
(3.66-4.31)\end{array}$ & $\begin{array}{l}4.16 \pm 0.27 \\
(3.56-4.69)\end{array}$ \\
\hline $\begin{array}{l}\text { Max. reached dominant } \\
\text { frequency }(\mathrm{kHz})\end{array}$ & $\begin{array}{l}4.80 \pm 0.21 \\
(4.39-5.34)\end{array}$ & $\begin{array}{l}4.07 \pm 0.08 \\
(3.96-4.26)\end{array}$ & $\begin{array}{l}4.56 \pm 0.23 \\
(4.26-5.01)\end{array}$ & $\begin{array}{l}4.40 \pm 0.27 \\
(4.12-4.59)\end{array}$ & $\begin{array}{l}4.74 \pm 0.27 \\
(4.31-5.34)\end{array}$ \\
\hline $\begin{array}{l}1^{\text {st }} \text { Quartile Frequency } \\
(\mathrm{kHz})\end{array}$ & $\begin{array}{l}4.52 \pm 0.15 \\
(4.13-4.78)\end{array}$ & $\begin{array}{l}3.84 \pm 0.13 \\
(3.72-4.09)\end{array}$ & $\begin{array}{l}4.26 \pm 0.23 \\
(3.96-4.73)\end{array}$ & $\begin{array}{l}4.12 \pm 0.41 \\
(3.79-4.40)\end{array}$ & $\begin{array}{l}4.33 \pm 0.26 \\
(3.75-4.82)\end{array}$ \\
\hline $\begin{array}{l}3^{\text {rd }} \text { Quartile Frequency } \\
(\mathrm{kHz})\end{array}$ & $\begin{array}{l}4.70 \pm 0.18 \\
(4.26-5.06)\end{array}$ & $\begin{array}{l}3.96 \pm 0.12 \\
(3.85-4.18)\end{array}$ & $\begin{array}{l}4.43 \pm 0.24 \\
(4.13-4.87)\end{array}$ & $\begin{array}{l}4.26 \pm 0.34 \\
(3.94-4.50)\end{array}$ & $\begin{array}{l}4.59 \pm 0.26 \\
(4.03-5.16)\end{array}$ \\
\hline $\begin{array}{l}\text { Peak of } 2^{\text {nd }} \text { harmonic } \\
\text { frequency }(\mathrm{kHz})\end{array}$ & $\begin{array}{c}9.20 \pm 0.40 \\
(8.35-10.22)\end{array}$ & $\begin{array}{l}7.77 \pm 0.11 \\
(7.60-7.99)\end{array}$ & $\begin{array}{l}8.47 \pm 0.22 \\
(7.97-8.74)\end{array}$ & $\begin{array}{c}7.64-7.87 \\
(\mathrm{~N}=1)\end{array}$ & $\begin{array}{l}8.72 \pm 0.46 \\
(7.50-9.56)\end{array}$ \\
\hline Air temperature $\left({ }^{\circ} \mathrm{C}\right)$ & $26.8-29.6$ & 26 & $24.0-28.8$ & 26 & 27 \\
\hline Water temperature $\left({ }^{\circ} \mathrm{C}\right)$ & 27.8 & - & $25-26$ & 30 & 27 \\
\hline
\end{tabular}


Table 2. Confusion matrix for the comparisons with Pseudopaludicola parnaiba Roberto, Cardozo \& Ávila, 2013 based on acoustic dataset by means of a randomForests model. Settings: number of tree permutations $=1000$; number of variables tried at each split $=3.0$; error rate $=30.91 \%$.

\begin{tabular}{lccccc}
\hline & P. canga & P. parnaiba & $\begin{array}{c}\text { Pseudopaludicola } \\
\text { sp. 3 }\end{array}$ & $\begin{array}{c}\text { P. canga from the } \\
\text { state of Tocantins }\end{array}$ & $\begin{array}{c}\text { classification } \\
\text { error }\end{array}$ \\
\hline $\begin{array}{l}\text { P. canga } \\
\text { P. parnaiba }\end{array}$ & 3 & 0 & 0 & 0 & $0 \%$ \\
$\begin{array}{l}\text { Pseudopaludicola } \\
\text { sp. 3 }\end{array}$ & 0 & 9 & 7 & 0 & $44 \%$ \\
$\begin{array}{l}\text { P. canga from the } \\
\text { state of Tocantins }\end{array}$ & 0 & 1 & 23 & 0 & $21 \%$ \\
\hline
\end{tabular}

P. florencei Andrade, Haga, Lyra, Leite, Kwet, Haddad, Toledo \& Giaretta, 2018, P. restinga Cardozo, Baldo, Pupin, Gasparini \& Haddad, 2018, P. pocoto Magalhães, Loebmann, Kokubum, Haddad \& Garda, 2014, P. matuta Andrade, Haga, Lyra, Carvalho, Haddad, Giaretta \& Toledo, 2018, P. mineira Lobo, 1994, P. murundu Toledo, Siqueira, Duarte, Veiga-Menoncello, Recco-Pimentel \& Haddad, 2010, P. saltica (Cope, 1887) and P. jaredi Andrade, Magalhães, Nunes-de-Almeida, Veiga-Menoncello, Santana, Garda, Loebmann, Recco-Pimentel, Giaretta \& Toledo, 2016 (Fig. 3). Pseudopaludicola falcipes is a sister taxon of all other species in this subclade, but the relationships among $P$. florence + $P$. restinga + P. pocoto, $P$. matuta $+P$. mineira, and $P$. murundu $+P$. saltica $+P$. jaredi have a moderate bootstrap support $(\mathrm{BS}=88)$. The other subclade contains four members of the five known members of the P. pusilla species group (sensu Lynch 1989), P. llanera, P. boliviana Parker, 1927, P. motorzinho Pansonato, Veiga-Menoncello, Mudrek, Jansen, Recco-Pimentel, Martins \& Strüssmann, 2016 and P. pusilla, but with a low bootstrap support (BS $=43$; Fig. 3 ).

The second major clade also includes two well supported subclades: one composed of P. ameghini (Cope, 1887) and P. ternetzi Miranda-Ribeiro, 1937 (clade II $(2 \mathrm{n}=20)$ from Veiga-Menoncello et al. 2014; Fig. 3). The other subclade includes P. canga, P. facureae, P. atragula, Pseudopaludicola sp. (Palmeiras de Goiás, GO), P. mystacalis (Cope, 1887), P. jazmynmcdonaldae Andrade, Silva, Koroiva, Fadel \& Santana, 2019 and $P$. giarettai (clades III $(2 n=18)$ and IV $(2 n=16)$ of Veiga-Menoncello et al. 2014; Fig. 3). In this subclade, P. canga was recovered as a sister taxon of P. facureae + P. atragula + Pseudopaludicola sp. (Palmeiras de Goiás, GO), with a maximum bootstrap support for these relationships (Fig. 3); and P. giarettai was recovered as a sister taxon of P. mystacalis $+P$. jazmynmcdonaldae, with a moderate support (BS $=88$; Fig. 3 ). The four sequences of the specimens of $P$. giarettai from the type locality and Grande Sertão Veredas National Park were nested together in the topology (Fig. 3). This park is $400 \mathrm{~km}$ north of the type locality.

\section{Taxonomic accounts}

\section{Synonymy}

The acoustic and genetic analyses did not allow the discrimination between P. parnaiba and P. canga. Given that the phylogenetic positions and call data could not distinguish these two species, no current evidence remains to consider P. parnaiba as a different species from $P$. canga, and we consider that P. parnaiba Roberto, Cardozo \& Ávila, 2013 should be treated as a junior synonym of $P$. canga Giaretta \& Kokubum, 2003, following the Principle of Priority of the International Code of Zoological Nomenclature (ICZN 1999, Article 23). 
P. canga (type locality) $P$. parnaiba (type locality) Pseudopaludicola sp. $3 \bigcirc P$. canga (state of Tocantins)

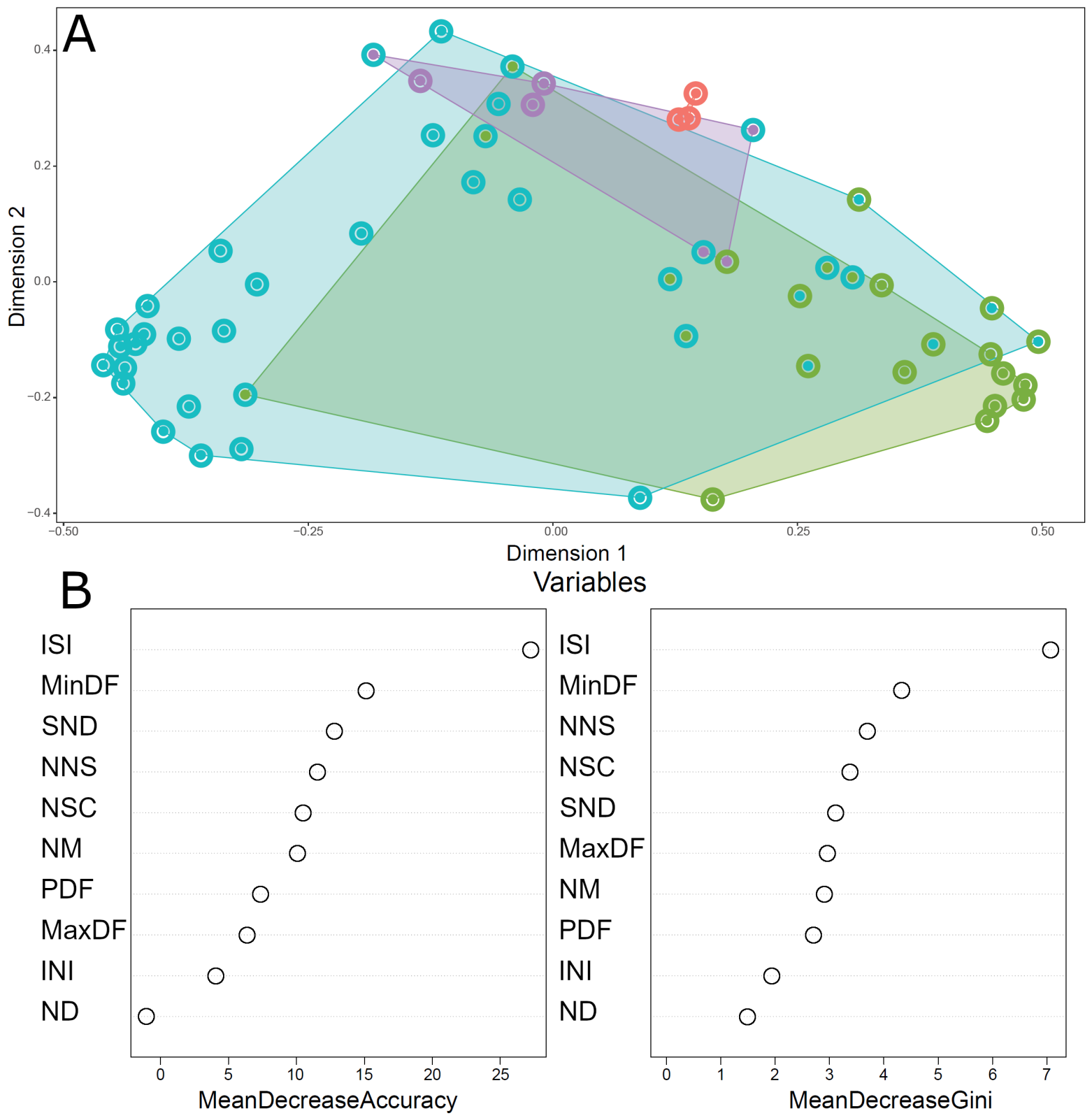

Fig. 2. A. First and second dimensions of the Multidimensional scaling on the proximity scores from the randomForest analysis considering acoustic traits of adult males of Pseudopaludicola canga Giaretta \& Kokubum, 2003 from the type locality (red dots), P. parnaiba Roberto, Cardozo \& Ávila, 2013 from the type locality (green dots), Pseudopaludicola sp. 3 sensu Veiga-Menoncello et al. 2014 (blue dots) and $P$. canga from TO (purple dots). Each dot represents an adult male. The circles around the dots represent how males were classified. B. Dotcharts of variable importance score considering acoustic traits as indicated by the randomForest analysis. 


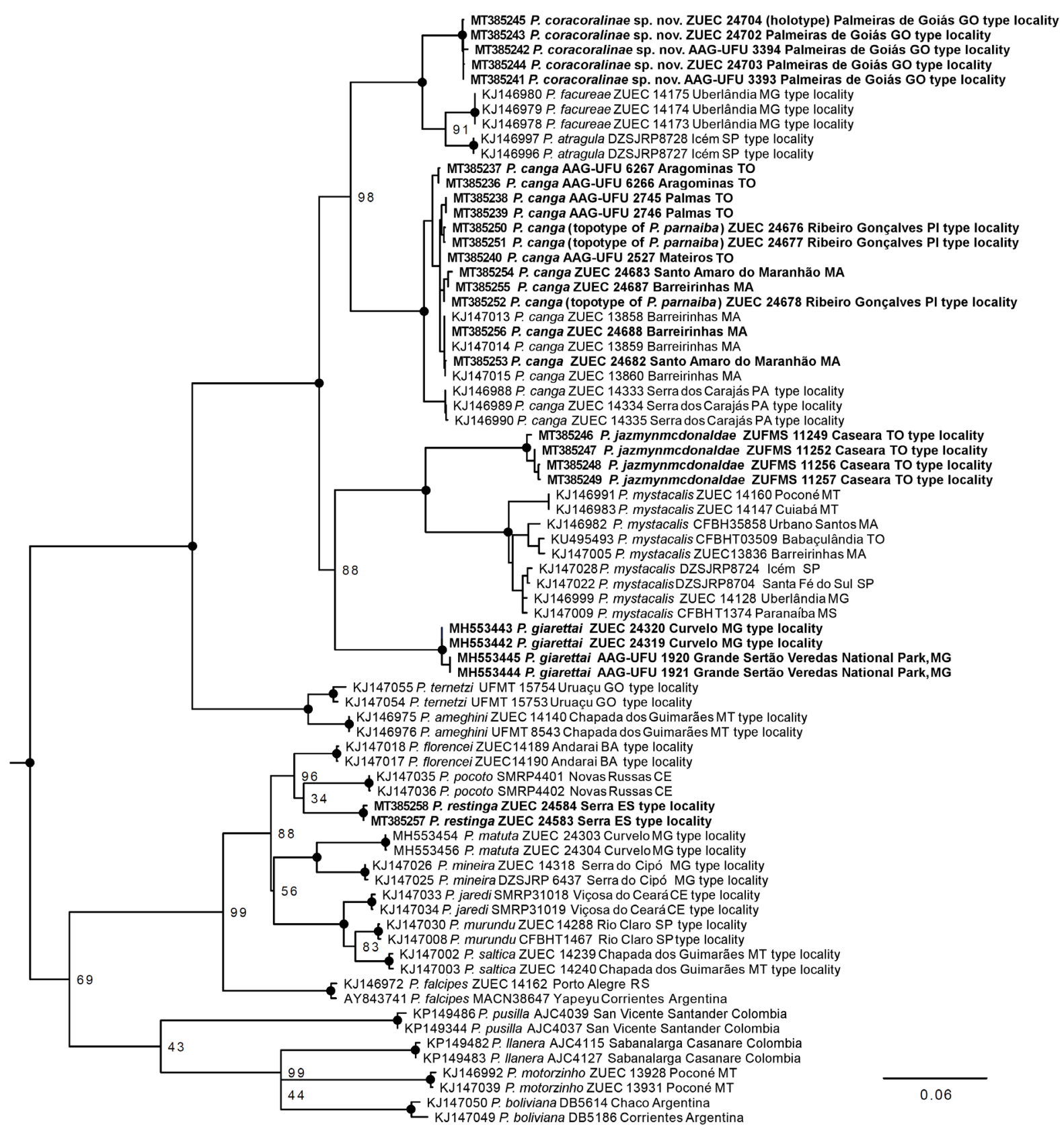

Fig. 3. Maximum likelihood tree recovered for the phylogenetic relationships of Pseudopaludicola Miranda-Ribeiro, 1926 based on the 12S rRNA, tRNA-val and 16S rRNA mitochondrial genes. Numbers near the nodes are bootstrap values and black dots represent bootstrap $=100$; support below species level is not shown. 


\section{Species description}

Class Amphibia Linnaeus, 1758

Order Anura Fischer von Waldheim, 1813

Family Leptodactylidae Werner, 1896 (1838)

Subfamily Leiuperinae Bonaparte, 1850

Genus Pseudopaludicola Miranda-Ribeiro, 1926

Pseudopaludicola coracoralinae sp. nov. urn:Isid:zoobank.org:act:FAB2ABCB-37D5-429C-9628-91BB62B185B6

Figs 4-5; Tables 3-4

Pseudopaludicola facureae from Palmeiras de Goiás, GO - Carvalho et al. 2015a: 267, 271, table 4, appendix 1-2.

\section{Diagnosis}

Pseudopaludicola coracoralinae sp. nov. is assigned to Pseudopaludicola by having a hypertrophied antebrachial tubercle (see Lynch 1989; Lobo 1995) and by its phylogenetic position within the genus. The new species is characterized by the following combination of characters: (1) upper eyelids smooth, without enlarged palpebral tubercles; (2) heel smooth, without conical tubercle; (3) single, subgular vocal sac, cream-colored with white or off-white warts; (4) terminal phalanges knobbed, without T-shaped terminal phalanges or expanded toe tips; (5) relative short hind limbs (tibio-tarsal articulation just reaching the corner of the mouth); (6) trilled advertisement call pattern, composed of 2-6 welldefined series of tonal notes, having each series of 7-116 notes, emitted at rates of 1485-2077 notes per minute.

\section{Etymology}

The specific name honors Anna Lins dos Guimarães Peixoto Bretas, better known by her pseudonym Cora Coralina. She was a simple woman, a Brazilian candy maker, writer and poetess. She was born and raised on the banks of the Vermelho River, in the municipality of Goiás, GO, and lived apart from urban centers. Cora Coralina studied until the third year of elementary school and did a typing course at the age of 70, due to a requirement of the publisher that would publish her first book. She is considered one of the most influential Brazilian writers. Although Cora Coralina wrote her first verses during her adolescence, she had her first book (Poemas dos Becos de Goiás e Estórias Mais) published in June 1965, when she was 75 years old. In 1984, the Brazilian Union of Writers awarded her the "literary personality of the year". Following that honor, Carlos Drummond de Andrade, another distinguished Brazilian poet, said: "I admire Cora Coralina and her mastery of living in a state of grace with her poetry. Her verse is like running waters, her lyricism has the power and delicacy of the natural world."

\section{Type material}

\section{Holotype}

BRAZIL • adult ${ }^{\top}$; state of Goiás, municipality of Palmeiras de Goiás; $16^{\circ} 46^{\prime} 59^{\prime \prime}$ S, 49 $52^{\circ} 2^{\prime \prime}$ W; $652 \mathrm{~m}$ a.s.1. (Fig. 1); 14 Mar. 2019; F.S. Andrade and I.A. Haga leg.; GenBank: MT385245; ZUEC 24704 (Figs 4, 5A).

\section{Paratypes}

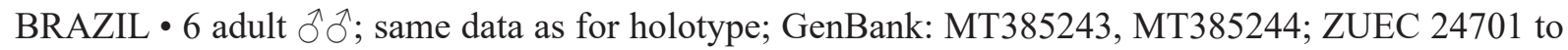
24703, 24707 to 24709 - 5 adult $q$ + ; same data as for holotype; ZUEC 24705, 24706, 24710 to 24712 •

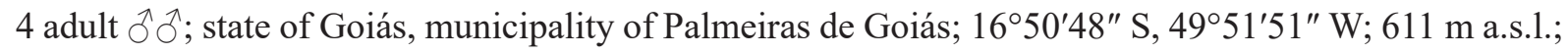


18 Dec. 2013; T.R. de Carvalho and L.B. Martins leg; GenBank: MT385241, MT385242; AAG-UFU 3393 to 3396.

\section{Type locality}

Brazil, GO, municipality of Palmeiras de Goiás (16 $46^{\prime} 59^{\prime \prime}$ S, 4952'2" W; 652 m a.s.1.; Fig. 1).

\section{Description of the holotype}

Body elliptic and broad (Fig. 4A-B; Table 3). Head elliptical, slightly wider than long. Snout subovoid in dorsal view and rounded in profile (Fig. 4C-D). Eye not protuberant. Eye diameter almost equal to interorbital distance. Interorbital area flat. Pupil rounded. Upper eyelid without tubercles. Nostril not protuberant and closer to snout tip than to eye. Canthus rostralis rounded, smooth. Loreal region slightly concave. Single subgular vocal sac, externally expanded with warty texture. Choanae rounded, well separated from each other. Vocal slits present. Tympanum membrane and annulus absent. Discrete tympanic ridge from behind eye to proximal portion of arm insertion. Mouth opening ventral. Vomerine teeth absent. Tongue ovoid, longer than wide, free posteriorly, without pigmentation at its base. Lateral of head and flanks with discrete granules. One ovoid antebrachial tubercle presents in first quarter of forearm. Finger and toe tips not expanded. Outer and inner metacarpal tubercles welldefined; outer metacarpal tubercle rounded and inner metacarpal tubercle ovoid. Fingers with single and rounded subarticular tubercles. Supernumerary tubercles absent on palm of hand. Thumb with discrete, keratinized, light brown nuptial pad, extending from base of hand to proximal limit of terminal phalanx, covering almost entire external portion of finger. Webbing absent between fingers. Relative finger lengths, when adpressed one to another: $\mathrm{I}<\mathrm{II}<\mathrm{IV}<\mathrm{III}$ (Fig. 4E). Outer metatarsal tubercle well defined, conical, smaller than ovoid inner metatarsal tubercle. Toes with well-defined, single, enlarged, rounded subarticular tubercles. Supernumerary tubercles absent on sole of foot. Toes webbed basally and fringed along their sides to almost their tips. Fringes developed on all toes (mainly on II, III, IV and $\mathrm{V})$. External fringe on Toe V continues almost to outer metatarsal tubercle. Well-developed fold from internal metatarsal tubercle to mid-ventral tarsus, ending in protuberant tarsal tubercle. Relative toe lengths, when adpressed one to another: $\mathrm{I}<\mathrm{II}<\mathrm{V}<\mathrm{III}<\mathrm{IV}$ (Fig. 4F). Hind limb robust with tibiotarsal articulation just reaching posterior margins of eye. Thigh shorter than tibia. Foot longer than thigh. Foot longer than tibia. Heel without tubercles. Belly skin smooth. Abdominal fold present and complete. Well-defined vertebral stripe from snout tip to vent. Dorsal surfaces of head, body and limbs smooth. Paravertebral chevron-shaped dermal ridge from behind eye to scapular region. Cloacal region smooth (Fig. 4B). Measurements of the holotype showed in Table 3.

\section{Color pattern of the holotype in preservative}

Dorsum brown with dark brown and black gray blotches. Belly whitish (unpigmented). Vocal sac creamcolored with white or off-white warts. Dorsum darker than dorsal surfaces of limbs. Region between upper lip and eye with several rounded white blotches with alternating vertical grey and light beige stripes. Ventral faces of arm and leg unpigmented. Palm of hand brown, pigmented. Sole of foot brown, pigmented and darker than hand, arm and hind limb. Color of sole of foot similar to that of dorsal region of hind limb. Dorsal face of arm light beige with several dark brown blotches. Dorsal face of limb light brown with dark brown transversal discontinuous stripes and with scattered brown blotches. Dark brown transverse stripes on arm (2-3), thigh (2-3), shank (2-3), foot (3-4). Light brown nuptial pads (Fig. 4).

\section{Variation in the type series}

Dorsal surface of body varies from brown to dark brown, with black or dark brown irregular blotches (Fig. 5). The specimen ZUEC 24705 does not have well-defined light vertebral line. The specimens ZUEC 24705-06, 24708-10 and AAG-UFU 3396 have no paravertebral chevron-shaped dermal ridges from behind the eyes to the scapular region. The specimens ZUEC 24702-03, 24706, 24710-12 and 


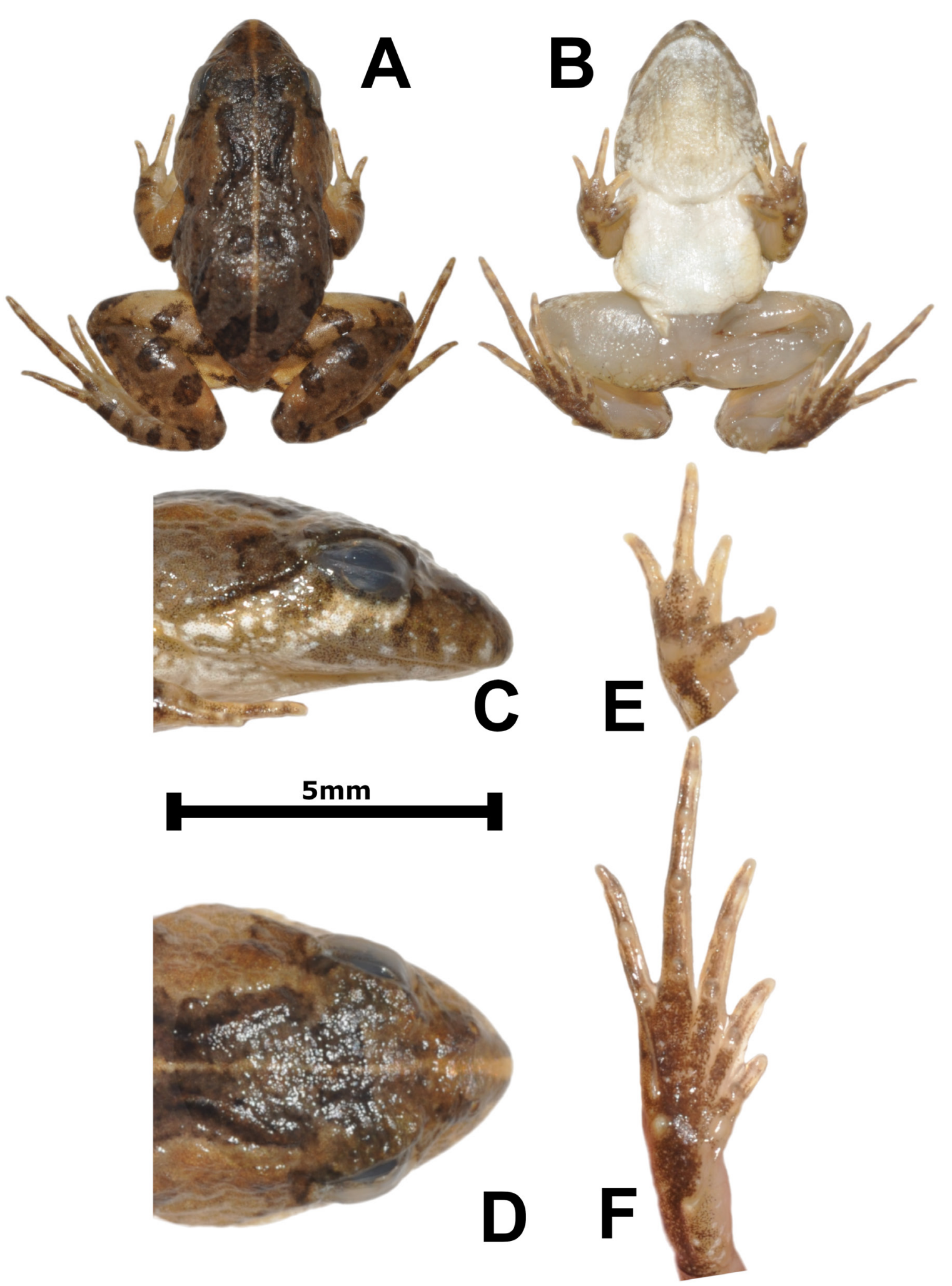

Fig. 4. Pseudopaludicola coracoralinae sp. nov., holotype (ZUEC 24704, SVL $=13.1 \mathrm{~mm}$ ), an adult $\widehat{\delta}$ from Palmeiras de Goiás, GO, Brazil. A. Dorsal view. B. Ventral view. C. Head, lateral view. D. Head, dorsal view. E. Right hand, ventral view. F. Right foot, ventral view. Scale bar (only for C, D, E, F) = $5 \mathrm{~mm}$. 
Table 3. Morphometry of Pseudopaludicola coracoralinae sp. nov. type series (including the holotype) from Palmeiras de Goiás, GO, Brazil. Values presented in millimeters as mean \pm standard deviation (minimum-maximum). $\mathrm{n}=$ number of measured specimens.

\begin{tabular}{llll}
\hline Characters & Holotype & Males (n = 10) & Females (n= 5) \\
\hline Snout-vent length (SVL) & 13.1 & $13.7 \pm 0.8(12.5-15.3)$ & $16.8 \pm 0.4(16.0-17.2)$ \\
Head length (HL) & 3.9 & $4.3 \pm 0.2(4.0-4.6)$ & $4.8 \pm 0.2(4.6-5.0)$ \\
Head width (HW) & 4.7 & $4.8 \pm 0.2(4.5-5.3)$ & $5.5 \pm 0.3(5.0-5.7)$ \\
Eye diameter (ED) & 1.5 & $1.6 \pm 0.0(1.5-1.6)$ & $1.8 \pm 0.2(1.5-2.1)$ \\
Interorbital distance (IOD) & 1.6 & $1.7 \pm 0.2(1.5-2.1)$ & $2.0 \pm 0.2(1.7-2.1)$ \\
Eye-nostril distance (END) & 1.0 & $1.1 \pm 0.1(1.0-1.2)$ & $1.4 \pm 0.2(1.1-1.5)$ \\
Snout length (SL) & 2.1 & $2.1 \pm 0.1(1.9-2.3)$ & $2.4 \pm 0.1(2.2-2.5)$ \\
Internarial distance (IND) & 1.2 & $1.2 \pm 0.1(1.0-1.4)$ & $1.5 \pm 0.0(1.4-1.5)$ \\
Hand length (HAL) & 3.6 & $3.9 \pm 0.2(3.5-4.2)$ & $4.5 \pm 0.2(4.2-4.8)$ \\
Thigh length (TL) & 6.2 & $6.5 \pm 0.3(6.0-7.0)$ & $7.7 \pm 0.3(7.2-8.0)$ \\
Tibia length (TBL) & 6.7 & $7.2 \pm 0.3(6.6-7.7)$ & $8.4 \pm 0.4(8.0-9.0)$ \\
Tarsus length (TAL) & 3.5 & $3.8 \pm 0.3(3.3-4.3)$ & $4.4 \pm 0.3(4.2-4.9)$ \\
Foot length (FL) & 7.2 & $7.9 \pm 0.4(7.3-8.5)$ & $9.2 \pm 0.5(8.6-9.8)$ \\
\hline
\end{tabular}

AAG-UFU 3393-96 have the region between upper lip and eye without alternating vertical stripes. The specimen ZUEC 24705 has no rounded white blotches on the region between upper lip and eye. The specimens ZUEC 24702, 24707-10, 24712 and AAG-UFU 3394 have dorsolateral stains on body, from posterior corner of eyes to almost the region of insertion of legs. The specimens ZUEC 24706, 24708-11 and AAG-UFU 3393 have no transverse stripes on arm.

\section{Advertisement call}

The advertisement call of the new species (total duration: 1.3-25.8 s) consists of 2-6 series of stereotyped tonal notes (non-pulsed) that last $0.2-4.1 \mathrm{~s}$, separated by intervals of $0.4-6.7 \mathrm{~s}$. Before the emission of the series of stereotyped tonal notes, $12-40$ (mean $=22.1, \mathrm{SD}=9.8)$ isolated notes with irregular structure, duration and interval are emitted, herein referred to as introductory notes (Fig. 6A). Introductory notes last 4-24 ms (mean 12, $\mathrm{SD}=3$ ), separated by intervals of 49-477 $\mathrm{ms}($ mean $=146, \mathrm{SD}=27)$, and their dominant frequency peaks between $3.62-5.16 \mathrm{kHz}$ (mean $=4.39, \mathrm{SD}=0.24)$. In contrast, within the series of stereotyped tonal notes, the notes have regular structure, duration and interval. These notes last 11-21 ms, separated by intervals of 12-61 ms, and are released at a rate of 1484.7-2076.6 notes per minute; notes have a slight increase in amplitude until the end of the first quartile of their durations, in the last quartile of their durations the notes suffer a decrease in amplitude (Fig. 6B). Dominant frequency peaks are between 4.18 and $5.06 \mathrm{kHz}$; the minimum frequency ranges between 3.84 and $4.59 \mathrm{kHz}$ and the maximum frequency ranges between 4.41 and $5.44 \mathrm{kHz}$. The notes have a slight increase in frequency along their durations; on average, the notes have an increase of $275 \mathrm{~Hz}$ from the first to the third quartiles of frequencies (Table 4). The dominant frequency coincides with the fundamental harmonic, and the second harmonic ranges between 8.34 and $10.50 \mathrm{kHz}$ (Fig. 6B). Air temperature of recorded calls varied from 22.2 to $26.0^{\circ} \mathrm{C}$. Traits that were classified as static (between-male $\mathrm{CV}<11 \%$ ) to P. coracoralinae sp. nov. were note duration, notes per minute and all spectral traits. The other traits were classified as dynamic. Call quantitative traits and CV values are summarized in Table 4. 


\section{Differential diagnosis}

Pseudopaludicola coracoralinae sp. nov. is promptly diagnosed from the P. pusilla species group (sensu Lynch 1989), which includes P. boliviana, P. ceratophyes Rivero \& Serna, 1985, P. llanera, P. pusilla and $P$. motorzinho, by the absence of either T-shaped terminal phalanges or expanded toe tips (discs or pads). The new species has terminal phalanges knobbed, similar in shape to those of $P$. falcipes (Cardozo \& Suárez 2012: fig. 2B). The new species is also distinguished from P. ceratophyes by having upper eyelids smooth; P. ceratophyes has upper eyelids with an enlarged palpebral tubercle (Lynch
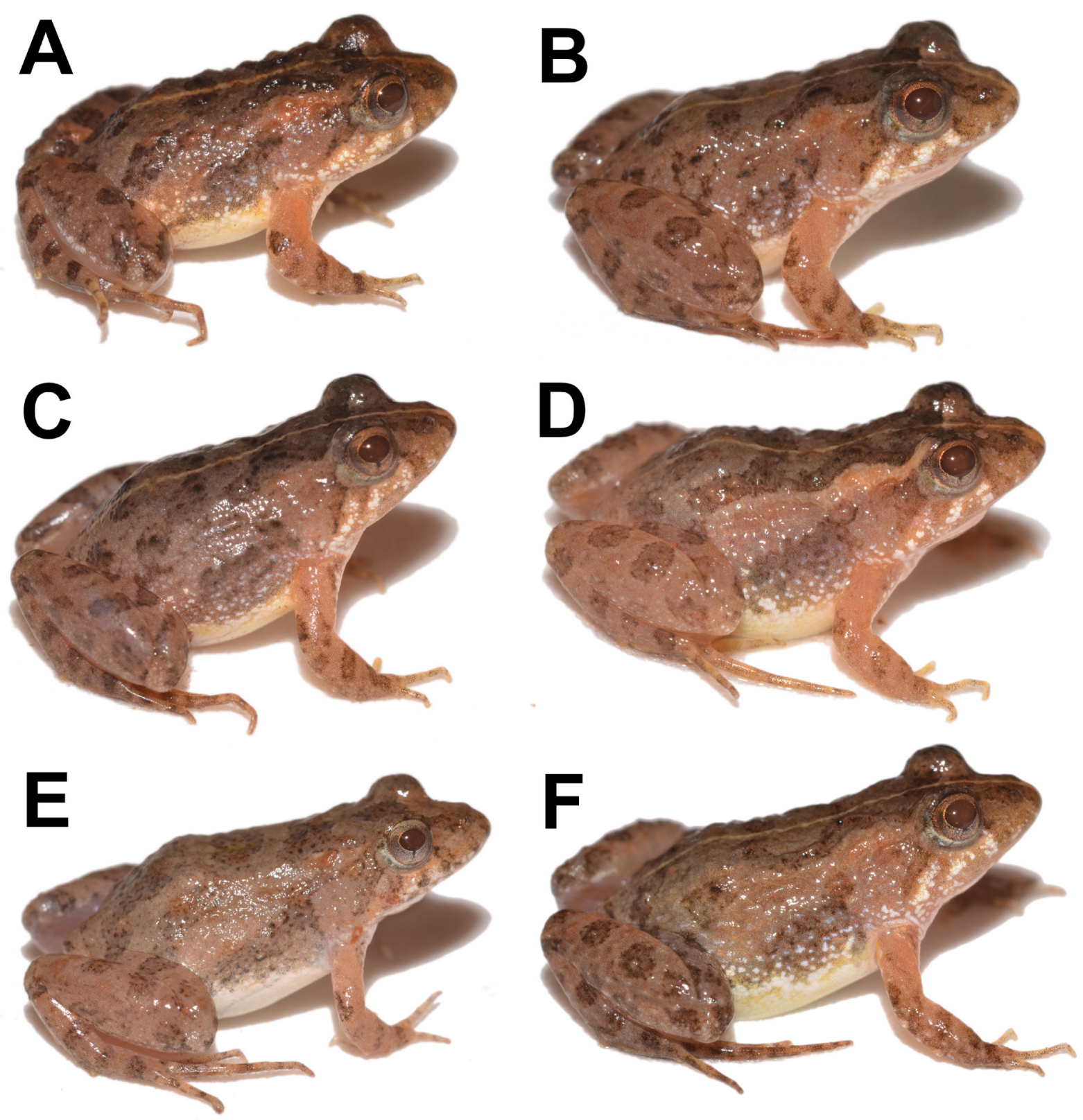

Fig. 5. Holotype and five paratypes of Pseudopaludicola coracoralinae sp. nov. in life. A. ZUEC 24704 (holotype, adult $\hat{\delta}$ and call voucher), $\mathrm{SVL}=13.1 \mathrm{~mm}$. B. ZUEC 24703 (adult $\delta$ and call voucher), $\mathrm{SVL}=13.2 \mathrm{~mm}$. C. ZUEC 24707 (adult $\precsim$ ), $\mathrm{SVL}=12.5 \mathrm{~mm}$. D. ZUEC 24712 (adult P), $\mathrm{SVL}=$ $16.0 \mathrm{~mm}$. E. ZUEC 24705 (adult + ), $\mathrm{SVL}=16.8 \mathrm{~mm}$. F. ZUEC 24706 (adult + ), $\mathrm{SVL}=17.0 \mathrm{~mm}$. 
1989). The new species also differs from $P$. boliviana, P. ceratophyes, $P$. llanera and $P$. motorzinho by having a smooth heel, without enlarged, conical tubercle (Lynch 1989; Pansonato et al. 2016).

Pseudopaludicola coracoralinae sp. nov. is promptly distinguished from the $P$. saltica species group that includes $P$. saltica, $P$. murundu and $P$. jaredi, by having short hind limbs (tibiotarsal articulation reaching near the corner of the mouth), whereas all three above-mentioned species have long hind limbs (tibiotarsal articulation extending beyond the tip of snout; Andrade et al. 2016).

The color and skin texture of the vocal sac of the P. coracoralinae sp. nov. is whitish cream with white or off-white warts (Fig. 4B), thereby distinguishing it from all congeners, except from $P$. facureae. Pseudopaludicola ameghini, P. ternetzi, P. falcipes, P. giarettai, P. hyleaustralis Pansonato, Morais, Ávila, Kawashita-Ribeiro, Strussmann \& Martins, 2012, P. canga, P. florencei, P. pocoto, P. mineira, P. restinga, $P$. matuta, . mystacalis, $P$. ceratophyes, $P$. llanera, $P$. boliviana, $P$. motorzinho, $P$. ibisoroca Pansonato, Veiga-Menoncello, Mudrek, Jansen, Recco-Pimentel, Martins \& Strüssmann, 2016 and $P$. saltica have vocal sacs that are whitish, yellowish, or light cream with no warty texture (combined characters of the vocal sac of all above-mentioned species: Miranda-Ribeiro 1937; Ruthven 1916; Rivero \& Serna 1985; Haddad \& Cardoso 1987; Lynch 1989; Lobo 1994; Giaretta \& Kokubum 2003; Carvalho 2012; Pansonato et al. 2012, 2013, 2016; Roberto et al. 2013; Magalhães et al. 2014; Carvalho et al. 2015b, Andrade et al. 2017a, 2018a, 2018b; Cardozo et al. 2018); P. jazmynmcdonaldae has a dark and smooth vocal sac with no warty texture (Andrade et al. 2019); and P. atragula has a white vocal sac with warty texture and dark-colored reticulations (Pansonato et al. 2014a).

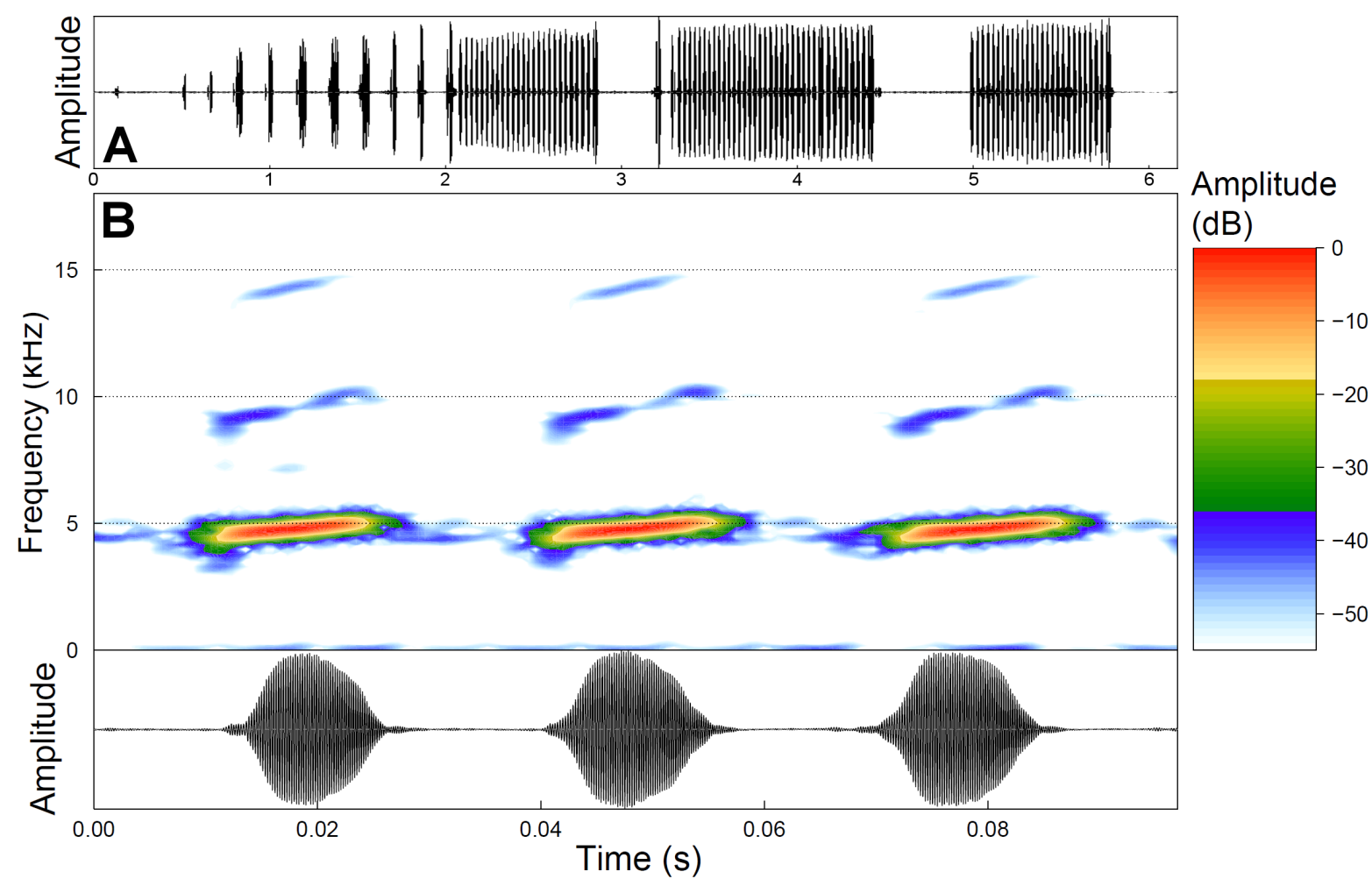

Fig. 6. A. Oscillogram of the entire advertisement call of Pseudopaludicola coracoralinae sp. nov. with the introductory notes followed by three series of tonal notes. B. Audiospectrogram (top) and corresponding oscillogram (bottom) detailing three notes. The male was recorded on 8 November 2016 at $18: 08 \mathrm{~h}$; air temperature $26^{\circ} \mathrm{C}$, water temperature $29^{\circ} \mathrm{C}$; recording_label: Pseudop_ coracoralinaePalmeirasGoiasGO5cFSA_AAGmt. 
ANDRADE F.S. et al., Taxonomic status of P. parnaiba and a new congeneric species

Table 4. Advertisement call traits based on the recordings of Pseudopaludicola coracoralinae sp. nov. and $P$. facureae Andrade \& Carvalho, 2013, both from the type localities. Values presented as mean \pm standard deviation (minimum-maximum). $\mathrm{CV}=$ between-male coefficient of variation; $\mathrm{n}=$ analyzed males (analyzed notes).

\begin{tabular}{|c|c|c|}
\hline & $\begin{array}{l}\text { P. coracoralinae sp. nov. } \\
\mathrm{n}=18 \text { (334) }\end{array}$ & $\begin{array}{l}\text { P. facureae } \\
\mathrm{n}=19(372)\end{array}$ \\
\hline Call duration (s) & $\begin{array}{l}7.2 \pm 6.4(1.3-25.8) \\
\mathrm{CV}=88.9 \%\end{array}$ & $\begin{array}{l}12.3 \pm 6.3(4.7-22.6) \\
C V=51.2 \%\end{array}$ \\
\hline Series of notes duration (s) & $\begin{array}{l}1.0 \pm 0.6(0.2-4.1) \\
\mathrm{CV}=60.0 \%\end{array}$ & $\begin{array}{l}0.5 \pm 0.1(0.1-3.5) \\
\mathrm{CV}=20.0 \%\end{array}$ \\
\hline Interseries interval (s) & $\begin{array}{l}1.0 \pm 0.5(0.4-6.7) \\
\mathrm{CV}=50.0 \%\end{array}$ & $\begin{array}{l}0.6 \pm 0.1(0.1-1.4) \\
\mathrm{CV}=16.7 \%\end{array}$ \\
\hline Number of series per call & $\begin{array}{l}3.2 \pm 1.2(2.0-6.0) \\
\mathrm{CV}=37.5 \%\end{array}$ & $\begin{array}{l}9.9 \pm 5.9(4.0-20.0) \\
\mathrm{CV}=59.6 \%\end{array}$ \\
\hline Number of notes per series & $\begin{array}{l}28.7 \pm 15.7(7.0-116.0) \\
C V=54.7 \%\end{array}$ & $\begin{array}{l}12.7 \pm 2.9(2.0-74.0) \\
\mathrm{CV}=22.8 \%\end{array}$ \\
\hline Note duration (ms) & $\begin{array}{l}15 \pm 1(11-21) \\
\mathrm{CV}=6.6 \%\end{array}$ & $\begin{array}{l}19 \pm 3(11-30) \\
\mathrm{CV}=15.8 \%\end{array}$ \\
\hline Internote interval (ms) & $\begin{array}{l}19 \pm 4(12-61) \\
\mathrm{CV}=21.1 \%\end{array}$ & $\begin{array}{l}24 \pm 8(11-156) \\
\mathrm{CV}=33.3 \%\end{array}$ \\
\hline Notes/minute & $\begin{array}{l}1796.1 \pm 123.1(1484.7-2076.6) \\
C V=6.8 \%\end{array}$ & $\begin{array}{l}1381.4 \pm 197.2(512.1-1842.6) \\
\mathrm{CV}=14.3 \%\end{array}$ \\
\hline Peak of dominant frequency $(\mathrm{kHz})$ & $\begin{array}{l}4.60 \pm 0.22(4.18-5.06) \\
\mathrm{CV}=4.8 \%\end{array}$ & $\begin{array}{l}4.35 \pm 0.25(3.84-4.99) \\
\mathrm{CV}=5.7 \%\end{array}$ \\
\hline Min. reached dominant frequency $(\mathrm{kHz})$ & $\begin{array}{l}4.27 \pm 0.22(3.84-4.59) \\
C V=5.2 \%\end{array}$ & $\begin{array}{l}4.11 \pm 0.26(3.61-4.74) \\
C V=6.3 \%\end{array}$ \\
\hline Max. reached dominant frequency $(\mathrm{kHz})$ & $\begin{array}{l}4.95 \pm 0.27(4.41-5.44) \\
\mathrm{CV}=5.5 \%\end{array}$ & $\begin{array}{l}4.66 \pm 0.29(4.12-5.21) \\
\mathrm{CV}=6.2 \%\end{array}$ \\
\hline $1^{\text {st }}$ Quartile Frequency $(\mathrm{kHz})$ & $\begin{array}{l}4.46 \pm 0.21(4.12-4.87) \\
C V=4.7 \%\end{array}$ & $\begin{array}{l}4.26 \pm 0.27(3.75-4.87) \\
C V=6.3 \%\end{array}$ \\
\hline $3^{\text {rd }}$ Quartile Frequency $(\mathrm{kHz})$ & $\begin{array}{l}4.73 \pm 0.23(4.26-5.16) \\
C V=4.9 \%\end{array}$ & $\begin{array}{l}4.47 \pm 0.27(3.94-5.08) \\
C V=6.0 \%\end{array}$ \\
\hline Peak of $2^{\text {nd }}$ harmonic frequency $(\mathrm{kHz})$ & $\begin{array}{l}9.32 \pm 0.57(8.34-10.50) \\
C V=6.1 \%\end{array}$ & $\begin{array}{l}8.81 \pm 0.57(6.98-10.25) \\
C V=6.5 \%\end{array}$ \\
\hline Air temperature $\left({ }^{\circ} \mathrm{C}\right)$ & $22.2-26.0$ & $21.0-31.0$ \\
\hline Water temperature $\left({ }^{\circ} \mathrm{C}\right)$ & $24.2-29.0$ & $21.0-31.0$ \\
\hline
\end{tabular}

The trilled pattern of its advertisement call (presence of non-pulsed notes) promptly distinguishes the new species from all species of Pseudopaludicola that have notes with pulsatile structure (pulses separated by silence intervals or not): P. ameghini, P. atragula, P. boliviana, P. falcipes, P. florencei, P. ibisoroca, P. jaredi, P. jazmynmcdonaldae, P. matuta, P. mineira, P. motorzinho, P. murundu, P. mystacalis, P. pocoto, P. restinga, P. saltica and P. ternetzi (Haddad \& Cardoso 1987; Duré et al. 2004; Pereira \& Nascimento 2004; Pansonato et al. 2013, 2014a, 2014b, 2016; Magalhães et al. 2014; Andrade et al. 2016, 2017a, 2017b, 2018a, 2018b, 2019; Cardozo et al. 2018). 


\section{Acoustic comparison with its sister species}

Pseudopaludicola coracoralinae sp. nov. and P. facureae are indistinguishable in external morphology, but the new species was recovered as a sister species of $P$. facureae $+P$. atragula (Fig. 3). Furthermore, the RF multivariate approach applied to morphometric data indicated a broad overlap between the two partitions (Fig. 7A-B), with a considerable classification error (Table 5). In relation to three species of Pseudopaludicola that share the trilled advertisement call pattern (P. hyleaustralis, $P$. facureae and $P$. canga), $P$. facureae is the one with the most similar call to that of $P$. coracoralinae sp. nov. The trait of notes per minute distinguishes the new species (1485-2077 notes per minute) from P. canga and P. hyleaustralis (368-1286 notes per minute; combined values, Table 1; see Carvalho et al. 2015a). The RF multivariate analysis on acoustic data indicated a complete segregation between $P$. coracoralinae sp. nov. and $P$. facureae, without any classification error (Table 5; Fig. 7C). Notes per minute (P. coracoralinae sp. nov. $1796 \pm 123$ (1485-2077) vs $P$. facureae $1383 \pm 192$ (512-1843)), number of series per call (P. coracoralinae sp. nov. $3 \pm 1(2-6)$ vs $P$. facureae $10 \pm 6(4-20))$ and number of notes per series (P. coracoralinae sp. nov. $29 \pm 16(7-116)$ vs $P$. facureae $17 \pm 18(2-93)$ ) were the main sources of variation in both variable importance measurements (Fig. 7D). In addition to these abovementioned traits, we found differences $(P \leq 0.01)$ between these two species in note duration, internote interval, series of notes duration, interseries interval and dominant frequency.

\section{Phylogenetic inference and genetic distances of the new species}

Pseudopaludicola coracoralinae sp. nov. was recovered as a sister species of the P. atragula + P. facureae clade (Fig. 3). Uncorrected genetic distance between the P. coracoralinae sp. nov. and P. atragula was $4.5 \%$ (mean value), and from $P$. facureae, it was $4.9 \%$ (mean value). The maximum intraspecific distance was $0.4 \%$ (Supplementary file 2). No molecular data are available for $P$. ceratophyes, $P$. hyleaustralis and P. ibisoroca; however, the new species is easily diagnosed from these species by morphology and acoustics (see further details in Differential diagnosis section).

\section{Natural history notes}

Males of the new species were found calling in a partially flooded open area surrounded by a newly planted cornfield (corn stalk $<40 \mathrm{~cm}$ tall). We collected the holotype and ZUEC's paratypes at this site. The AAG-UFU's paratypes were collected in another partially flooded open area near to a permanent lagoon at the margins of the GO-156 highway. We observed three couples in axillary amplexus in the field. In our field recordings of vocalizations, the males were vocalizing well-spaced from each other, without any close-range encounters. The new species was observed syntopically with Leptodactylus fuscus (Schneider, 1799) and Physalaemus marmoratus (Reinhardt \& Lütken, 1862) at its type locality. Curiously, the congener Pseudopaludicola mystacalis was observed about 50 meters in a similar partially flooded open area surrounded by the same cornfield. We heard and observed only P. mystacalis at this site, not $P$. coracoralinae sp. nov.

\section{Distribution}

Pseudopaludicola coracoralinae sp. nov. is known only from the type locality (Fig. 1). However, we are aware of other populations that have trilled advertisement calls similar to those of $P$. coracoralinae sp. nov. and P. facureae. These populations occur in Limeira do Oeste, MG (Andrade \& Carvalho 2013); Goianésia, Piracanjuba and in the Altamiro de Moura Pacheco State Park, all in GO, Brazil (Guimarães et al. 2001; Carvalho et al. 2015a; Ramalho et al. 2018). Goianésia is about $180 \mathrm{~km}$ northeast from the type locality of $P$. coracoralinae sp. nov., Piracanjuba is about $100 \mathrm{~km}$ southeast and the Altamiro de Moura Pacheco State Park is about $80 \mathrm{~km}$ northeast. Limeira do Oeste is closer to the type locality of $P$. facureae, about $250 \mathrm{~km}$ east. However, the specific identities of these populations will only be confirmed when their genetic information is available because they are morphologically and acoustically cryptic. 
Table 5. Confusion matrix for Pseudopaludicola coracoralinae sp. nov. and $P$. facureae Andrade \& Carvalho, 2013 based on morphometric and acoustic (values in bold) datasets by means of a randomForests model. Settings: number of tree permutations $=1000$; number of variables tried at each split $=3.0$; error rates $=29.2 \% \mid \mathbf{0 \%}$.

\begin{tabular}{llll}
\hline & P. coracoralinae sp. nov. & P. facureae & classification error \\
\hline P. coracoralinae sp. nov. & $8 \mid \mathbf{1 8}$ & $3 \mid \mathbf{0}$ & $27 \% \mid \mathbf{0 \%}$ \\
P. facureae & $4 \mid \mathbf{0}$ & $9 \mid \mathbf{1 9}$ & $31 \% \mid \mathbf{0 \%}$ \\
\hline
\end{tabular}

\section{Discussion}

The acoustic characterization of P. parnaiba showed here is in accordance with that of Carvalho et al. (2015a), and we were also unable to found reliable diagnostic characters between P. parnaiba and $P$. canga. In addition, the phylogenetic positions of the topotypes of $P$. parnaiba did not support the hypothesis that it evolved independently of $P$. canga. Therefore, $P$. parnaiba is regarded herein as a junior synonym of $P$. canga. Hence, the distribution of $P$. canga has increased considerably, occurring in four Brazilian states: PA (Marabá, type locality), MA (Barreirinhas and Santo Amaro do Maranhão), TO (Aragominas, Mateiros and Palmas) and PI (Ribeiro Gonçalves).

We analyzed calls from São Desidério, BA, and concluded that these individuals represent $P$. canga, since the values of all their traits overlapped those described for this species in the present study. Therefore, this is the first record of $P$. canga for BA about $900 \mathrm{~km}$ southeast from the type locality. Oliveira et al. (2013) provided another locality for $P$. canga in PA, in the municipality of Brasil Novo. However, this record was based only on morphological information. Recently, Andrade et al. (2018c) reported on its larval morphology based on tadpoles from Mirador State Park, southern MA.

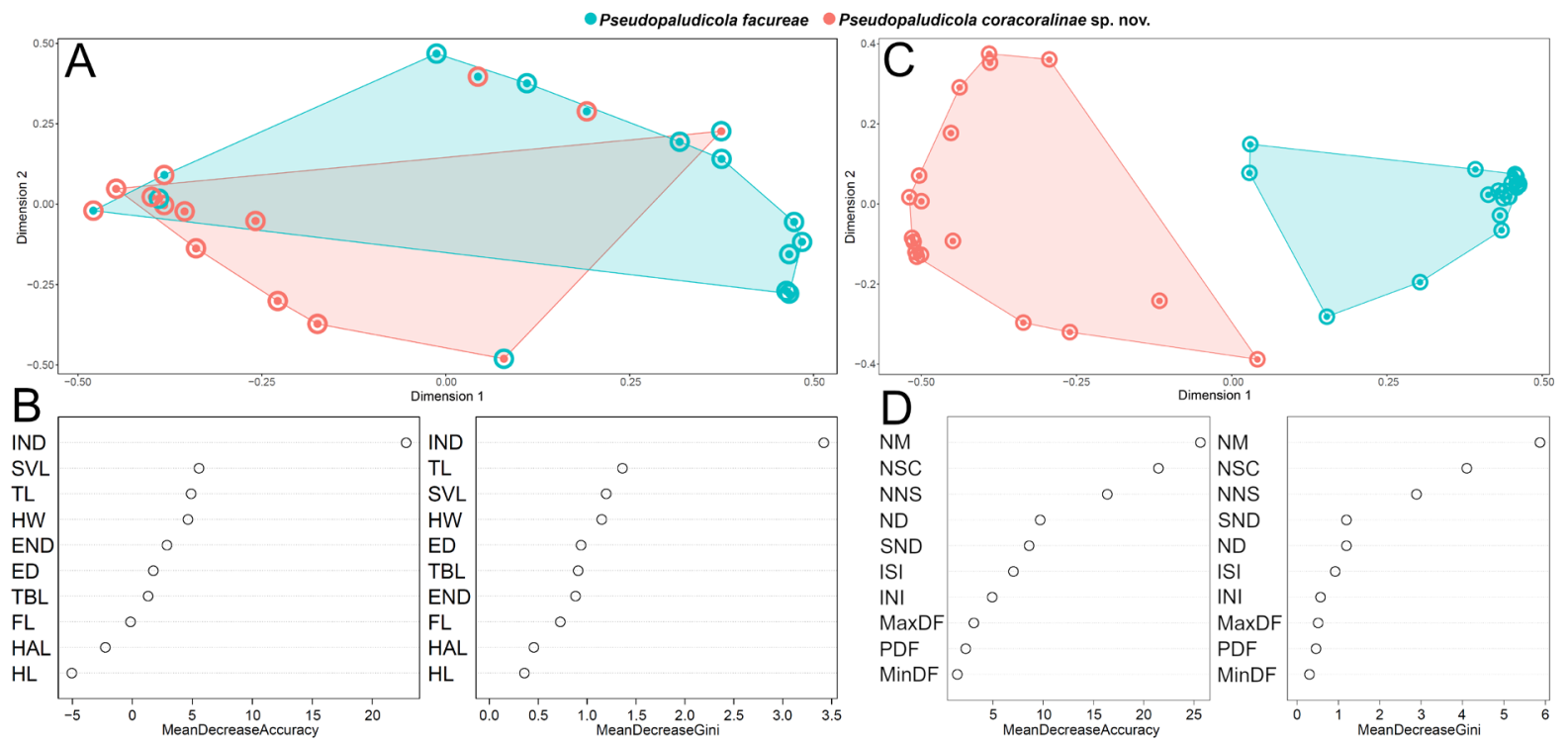

Fig. 7. A, C. First and second dimensions of the Multidimensional scaling on the proximity scores from the randomForest analysis of adult males of Pseudopaludicola coracoralinae sp. nov. from the type locality (red dots) and P. facureae Andrade \& Carvalho, 2013 from the type locality (blue dots). A. Morphometric traits. C. Acoustic traits. Each dot represents an adult male. The circles around the dots represent how males were classified. B, D. Dotcharts of variable importance score as indicated by the randomForest analysis. B. Morphometric traits. D. Acoustic traits. 
Pseudopaludicola coracoralinae sp. nov. and P. facureae are morphometrically indistinguishable from each other. However, the phylogenetic positions of these two cryptic sister species provides sufficient evidence to support our hypothesis that these lineages evolved independently. Moreover, based on the $\mathrm{RF}$ results of the acoustic comparison between P. coracoralinae sp. nov. and P. facureae, notes per minute was the main source of variation in both variable importance measurements. This trait was classified as static in P. coracoralinae sp. nov. (sensu Gerhardt 1991), due to its low between-male variability. Gerhardt (1991) pointed out that the spectral and fine-scale temporal traits of the frog calls are usually important for species recognition, whereas variable temporal traits may be important for mate choice. Therefore, P. coracoralinae sp. nov. differs statistically from $P$. facureae in a temporal trait that is expected to be associated with their species recognition.

In addition, we found differences in the environment occupied by $P$. coracoralinae sp. nov. and $P$. facureae. The marshy areas of both sites where we recorded and collected P. coracoralinae sp. nov. in Palmeiras de Goiás were temporary (see details in the Natural history notes section). On the other hand, P. facureae was always found in permanent marshy areas, both in disturbed areas and along palm marshes (Veredas) in open grasslands (Giaretta \& Facure 2009; Andrade \& Carvalho 2013). Males of P. facureae called from slow flowing, shallow streamlets with clear water and a muddy bottom; they called sitting in or close to the water (Giaretta \& Facure 2009). In addition, P. facureae can reproduce continuously all year round (Giaretta \& Facure 2009). We did not visit the localities where P. coracoralinae sp. nov. occurs during the dry season, so we are unable to determine whether it breeds throughout the year as does $P$. facureae. In any case, the drying of temporary habitats should directly influence the reproduction of $P$. coracoralinae sp. nov.

Fišer et al. (2018) stated that evolutionary mechanisms leading to morphological similarity are heterogeneous, comprising recent divergence, niche conservatism and morphological convergence. Yet, those authors also argued that the biodiversity science is only just beginning to understand the 'invisible' world of cryptic species. They indicated that integrative approaches can reveal generalities in the speciation process, improving our understanding of the heterogeneity (species properties) in speciation, allowing a better integration in biodiversity science. Closely related species of Pseudopaludicola have similar external morphology and high intraspecific variation on dorsal color patterns (e.g., Andrade et al. 2017a), therefore, the association of multiple datasets is crucial for unequivocal identifications of Pseudopaludicola and to elucidate the hidden diversity within this Neotropical frog clade (Andrade et al. 2018a, 2018b, 2019). Thus, the identification of specimens of Pseudopaludicola based solely on their external morphology should be avoided in most cases. As an example, two recent studies failed in reporting the occurrence of $P$. falcipes for the Brazilian states GO and MG (Neves et al. 2019; Oliveira et al. 2019), because it is well-known that it does not occur in the Brazilian Cerrado (Langone et al. 2015, 2016).

The topology and interspecific relationships of the phylogeny proposed here for Pseudopaludicola species corroborated those topologies and relationships recovered previously (Veiga-Menoncello et al. 2014; Andrade et al. 2016, 2018a, 2018b, 2019). As in previously phylogenetic inferences, we were not able to find good support for nodes of some subclades of Pseudopaludicola (e.g., subclades of P. mineira + P. matuta and P. florencei + P. restinga + P. pocoto, and P. saltica species group). These low bootstrap values can be explained by the existence of unknown species that are not represented in the topologies available so far, i.e., the species richness of Pseudopaludicola still remains underestimated.

Here we include for the first time $P$. pusilla and P. llanera in a molecular phylogenetic inference of the genus. Although they are nested together with the other sampled species from P. pusilla group, it is worth highlighting the low support for this clade. However, we recall here that we obtained only the $16 \mathrm{~S}$ mitochondrial sequences of $P$. pusilla and $P$. llanera from the GenBank database, which were made 
available by Guarnizo et al. (2015). These authors preliminary identified and allocated to nominal species of their collected specimens using external morphology. They collected two specimens of P. pusilla in San Vicente, Santander, in the Magdalena River valley, western slope of the Eastern Cordillera (Colombia). Lynch (1989) restricted the distribution of $P$. pusilla to the lower and middle Magdalena River valley and to the Caribbean lowlands of northern Colombia and adjacent Venezuela. Therefore, we emphasize the need to sequence more markers for these Colombian specimens of $P$. pusilla, and further taxonomic studies with the species of this group, especially P. llanera, P. pusilla and P. ceratophyes. For example, there is no genetic information for $P$. ceratophyes yet. Also, acoustic data would be very important to better elucidate these taxonomic issues.

The increase of sampling efforts and the use of multiple datasets in Pseudopaludicola taxonomical studies have uncovered the striking species richness of these fascinating dwarf swamp frogs, especially in the last decade (e.g., Toledo et al. 2010; Pansonato et al. 2014a, 2016; Andrade et al. 2016, 2018a, 2018b, 2019; Cardozo et al. 2018). On the other hand, unsustainable agricultural activities, particularly soy production and cattle ranching, as well as burning of vegetation for charcoal, make the Cerrado one of the most threatened biodiversity hotspots (Strassburg et al. 2017). All these actions continue to pose a major threat to the Cerrado's biodiversity and despite its environmental importance and uniqueness, it is one of the least protected formations in Brazil. The recognition of the P. coracoralinae sp. nov. is important to the knowledge of the frog richness and diversification patterns that operated in this region. Future phylogeographic studies would be valuable to shed light on the evolutionary process of P. coracoralinae sp. nov., P. facureae and $P$. atragula.

\section{Acknowledgements}

Special thanks to A.C.P. Veiga-Menoncello who kindly made available some tissues of Pseudopaludicola spp.; B.F.V. Teixeira and C.S. Bernardes made available Pseudopaludicola spp. recordings. São Paulo Research Foundation (FAPESP) provided fellowships to FSA (\#2015/10728-7), TRC (\#2017/08489-0), MLL (\#2017/26162-8), and grants to LFT (\#2016/25358-3), and CFBH (\#2013/50741-7). Conselho Nacional de Desenvolvimento Científico e Tecnológico (CNPq) provided grants (\#446935/2014-0, \#152548/2011-4) and fellowships (\#305261/2010-0, \#300869/2016-6, \#306623/2018-8) to AAG, LFT, and CFBH. Fundação de Amparo à Pesquisa do Estado de Minas Gerais (FAPEMIG) provided a grant (\#APQ-01724-14) to AAG. Cornell Lab of Ornithology (Bioacoustics Research Program) provided licenses of Raven Pro.

\section{References}

Andrade F.S. \& Carvalho T.R. 2013. A new species of Pseudopaludicola Miranda-Ribeiro (Leiuperinae: Leptodactylidae: Anura) from the Cerrado of southeastern Brazil. Zootaxa 3608 (5): 389-397. https://doi.org/10.11646/zootaxa.3608.5.7

Andrade F.S., Magalhães F.M., Nunes-de-Almeida C.H.L., Veiga-Menoncello A.C.P., Santana D.J., Garda A.A., Loebmann D., Recco-Pimentel S.M., Giaretta A.A. \& Toledo L.F. 2016. A new species of long-legged Pseudopaludicola from northeastern Brazil (Anura, Leptodactylidae, Leiuperinae). Salamandra 52: 107-124.

Andrade F.S., Haga I.A., Bang D.L. \& Giaretta A.A. 2017a. The differential acoustic diagnosis between two Pseudopaludicola sister species (Anura, Leptodactylidae, Leiuperinae). Zootaxa 4319 (2): 391400. https://doi.org/10.11646/zootaxa.4319.2.12

Andrade F.S., Leite F.S.F., Carvalho T.R., Bernardes C.S. \& Giaretta A.A. 2017b. First record of Pseudopaludicola pocoto Magalhães, Loebmann, Kokubum, Haddad \& Garda, 2014 (Anura, Leptodactylidae, Leiuperinae) in Bahia state, northeastern Brazil, with further data on its advertisement call. Check List 13 (1): 2047. https://doi.org/10.15560/13.1.2047 
Andrade F.S., Haga I.A., Lyra M.L., Leite F.S.F., Kwet A., Haddad C.F.B., Toledo L.F. \& Giaretta A.A. 2018a. A new species of Pseudopaludicola Miranda-Ribeiro (Anura: Leptodactylidae: Leiuperinae) from eastern Brazil, with novel data on the advertisement call of Pseudopaludicola falcipes (Hensel). Zootaxa 4433 (1): 71-100. https://doi.org/10.11646/zootaxa.4433.1.4

Andrade F.S., Haga I.A., Lyra M.L., Carvalho T.R., Haddad C.F.B., Giaretta A.A. \& Toledo L.F. 2018 b. A new species of Pseudopaludicola (Anura, Leptodactylidae, Leiuperinae) from the state of Minas Gerais, Brazil. European Journal of Taxonomy 480: 1-25. https://doi.org/10.5852/ejt.2018.480

Andrade E.B., Ferreira J.S., Takazone A.M.G., Libório A.E.C. \& Weber L.N. 2018c. Description of the tadpole of Pseudopaludicola canga Giaretta and Kokubum, 2003 (Anura: Leptodactylidae). South American Journal of Herpetology 13: 64-72. https://doi.org/10.2994/SAJH-D-17-00032.1

Andrade F.S., Silva L.A., Koroiva R., Fadel R.M. \& Santana D.J. 2019. A new species of Pseudopaludicola Miranda-Ribeiro, 1926 (Anura: Leptodactylidae: Leiuperinae) from an Amazonia-Cerrado transitional zone, state of Tocantins, Brazil. Journal of Herpetology 53 (1): 68-80.

https://doi.org/10.1670/18-125

Archer E. 2018. rfPermute: Estimate Permutation p-values for Random Forest Importance Metrics (Computer software). R package ver. 2.0.1.

Available from https://CRAN.R-project.org/package=rfPermute [assessed 1 April 2019].

Bioacoustics Research Program. 2014. Raven Pro: Interactive Sound Analysis Software, ver. 1.5. The Cornell Lab of Ornithology, Ithaca, New York. Available from http://www.birds.cornell.edu/raven [accessed 5 Feb. 2015].

Brown S.D.J., Collins R.A., Boyer S., Lefort M.C., Malumbres-Olarte J., Vink C.J. \& Cruickshank R.H. 2012. SPIDER: an R package for the analysis of species identity and evolution, with particular reference to DNA barcoding. Molecular Ecology Resources 12: 562-565.

http://doi.org/10.1111/j.1755-0998.2011.03108.x

Cardozo D. \& Suárez P. 2012. Osteological description of Pseudopaludicola canga with implications for the taxonomic position of this taxon. Zootaxa 3515: 75-82. https://doi.org/10.11646/zootaxa.3515.1.6

Cardozo D.E., Baldo D., Pupin N., Gasparini J.L. \& Haddad C.F.B. 2018. A new species of Pseudopaludicola (Anura, Leiuperinae) from Espírito Santo, Brazil. PeerJ 6: e4766.

https://doi.org/10.7717/peerj.4766

Carvalho T.R. 2012. Anew species of Pseudopaludicola Miranda-Ribeiro (Leiuperinae: Leptodactylidae: Anura) from the Cerrado of southeastern Brazil with a distinctive advertisement call pattern. Zootaxa 3328: 47-54. https://doi.org/10.11646/zootaxa.3328.1.4

Carvalho T.R., Teixeira B.F.V., Martins L.B. \& Giaretta A.A. 2015a. Intraspecific variation and new distributional records for Pseudopaludicola species (Anura, Leptodactylidae, Leiuperinae) with trilled advertisement call pattern: diagnostic characters revisited and taxonomic implications. North-Western Journal of Zoology 11: 262-273.

Carvalho T.R., Borges-Martins M., Teixeira B.F.V., Godinho L.B. \& Giaretta A.A. 2015b. Intraspecific variation in acoustic traits and body size, and new distributional records for Pseudopaludicola giarettai Carvalho, 2012 (Anura, Leptodactylidae, Leiuperinae): implications for its congeneric diagnosis. Papéis Avulsos de Zoologia 55: 245-254. https://doi.org/10.1590/0031-1049.2015.55.17

Charif R.A., Waack A.M. \& Strickman L.M. 2010. Raven Pro 1.4 User's Manual. Cornell Lab of Ornithology, Cornell University, USA.

Available from http://ravensoundsoftware.com/wp-content/uploads/2017/11/Raven14UsersManual.pdf [assessed 3 Jun. 2020]. 
ANDRADE F.S. et al., Taxonomic status of P. parnaiba and a new congeneric species

de Queiroz K. 1998. The general lineage concept of species, species criteria, and the process of speciation and terminological recommendations. In: Howard D.J. \& Berlocher S.H. (eds) Endless Forms: Species and Speciation: 57-75. Oxford University Press, Oxford.

de Queiroz K. 2007. Species concepts and species delimitation. Systematic Biology 56 (6): 879-886. https://doi.org/10.1080/10635150701701083

Duré M.I., Schaefer E.F., Hamann M.I. \& Kehr A.I. 2004. Consideraciones ecológicas sobre la dieta, la reproducción y el parasitismo de Pseudopaludicola boliviana (Anura, Leptodactylidae) de Corrientes, Argentina. Phyllomedusa 3: 121-131. https://doi.org/10.11606/issn.2316-9079.v3i2p121-131

Fišer C., Robinson C.T. \& Malard F. 2018. Cryptic species as a window into the paradigm shift of the species concept. Molecular Ecology 27 (3): 613-635. https://doi.org/10.1111/mec.14486

Frost D.R. 2020. Amphibian Species of the World: an Online Reference. ver. 6.0. American Museum of Natural History, New York.

Available from http://research.amnh.org/herpetology/amphibia/index.html [accessed 3 Apr. 2020].

Gerhardt H.C. 1991. Female mate choice in treefrogs: static and dynamic acoustic criteria. Animal Behaviour 42: 615-635. https://doi.org/10.1016/S0003-3472(05)80245-3

Giaretta A.A. \& Kokubum M.N.C. 2003. A new species of Pseudopaludicola (Anura, Leptodactylidae) from northern Brazil. Zootaxa 383: 1-8. https://doi.org/10.11646/zootaxa.383.1.1

Giaretta A.A. \& Facure K.G. 2009. Habitat, egg-laying behaviour, eggs and tadpoles of four sympatric species of Pseudopaludicola (Anura, Leiuperidae). Journal of Natural History 43: 995-1009. https://doi.org/10.1080/00222930802702456

Guimarães L.D., Lima L.P., Juliano R.F. \& Bastos R.P. 2001. Vocalizações de espécies de anuros (Amphibia) no Brasil Central. Boletim do Museu Nacional, Zoologia (Nova Série) 474: 1-15. https://doi.org/10.1590/S0073-47212003000200005

Guarnizo C.E., Paz A., Muñoz-Ortiz A., Flechas S.V., Méndez-Narváez J. \& Crawford A.J. 2015. DNA Barcoding survey of anurans across the eastern cordillera of Colombia and the impact of the Andes on cryptic diversity. PLoS ONE 10 (5): e0127312. https://doi.org/10.1371/journal.pone.0127312

Haddad C.F.B. \& Cardoso A.J. 1987. Taxonomia de três espécies de Pseudopaludicola (Anura, Leptodactylidae). Papéis Avulsos de Zoologia 36: 287-300.

Haga I.A., Andrade F.S., Bruschi D.P., Recco-Pimentel S.M. \& Giaretta A.A. 2017. Unrevealing the leaf frogs Cerrado diversity: A new species of Pithecopus (Anura, Arboranae, Phyllomedusidae) from the Mato Grosso state, Brazil. PLoS ONE 12 (9): e0184631. https://doi.org/10.1371/journal.pone.0184631

Heyer W.R., Rand A.S., Cruz C.A.G., Peixoto O.L. \& Nelson C.E. 1990. Frogs of Boracéia. Arquivos de Zoologia 31: 235-410.

Hothorn T., Hornik K., Van De Wiel M.A. \& Zeileis A. 2008. Implementing a class of permutation tests: the coin package. Journal of Statistical Software 28: 1-23. https://doi.org/10.18637/jss.v028.i08

ICZN 1999. International Code of Zoological Nomenclature, $4^{\text {th }}$ Edition: adopted by the International Union of Biological Sciences. The International Trust for Zoological Nomenclature. Available from https://www.iczn.org/the-code/the-international-code-of-zoological-nomenclature/the-code-online/ [accessed 26 Mar. 2020].

Katoh K. \& Standley D.M. 2013. MAFFT multiple sequence alignment software version 7: improvements in performance and usability. Molecular Biology and Evolution 30 (4): 772-780.

https://doi.org/10.1093/molbev/mst010 
Köhler J., Jansen M., Rodríguez A., Kok P.J.R., Toledo L.F., Emmrich M., Glaw F., Haddad C.F.B., Rödel M.O. \& Vences M. 2017. The use of bioacoustics in anuran taxonomy: theory, terminology, methods and recommendations for best practice. Zootaxa 4251: 1-124. https://doi.org/10.11646/zootaxa.4251.1.1

Langone J.A., Lavilla E.O., Sá R.O. \& Cardozo D. 2015. Comments on the type locality, type series, and geographic distribution of Pseudopaludicola falcipes (Hensel, 1867) (Amphibia, Anura). Zootaxa 4058 (1): 145-150. https://doi.org/10.11646/zootaxa.4058.1.12

Langone J.A., Camargo A. \& Sá R.O. 2016. High genetic diversity but low population structure in the frog Pseudopaludicola falcipes (Hensel, 1867) (Amphibia, Anura) from the Pampas of South America. Molecular Phylogenetics and Evolution 95: 137-151. https://doi.org/10.1016/j.ympev.2015.11.012

Liaw A. \& Wiener M. 2002. Classification and regression by randomForest. $R$ News 2: 18-22.

Lobo F. 1994. Descripción de una nueva especie de Pseudopaludicola (Anura: Leptodactylidae), redescripción de P. falcipes (Hensel, 1867) y P. saltica (Cope, 1887). Cuadernos de Herpetología 8: 177-199.

Lobo F. 1995. Análisis filogenético del género Pseudopaludicola (Anura: Leptodactylidae). Cuadernos de Herpetologia 9: 21-43.

Lynch J.D. 1989. A review of leptodactylid frogs of the genus Pseudopaludicola in northern South America. Copeia 3: 577-588. https://doi.org/10.2307/1445483

Lyra M.L., Haddad C.F.B. \& Azeredo-Espin A.M.L. 2017. Meeting the challenge of DNA barcoding Neotropical amphibians: polymerase chain reaction optimization and new COI primers. Molecular Ecology Resources 17 (5): 966-980. https://doi.org/10.1111/1755-0998.12648

Magalhães F.M., Loebmann D., Kokubum M.N.C., Haddad C.F.B. \& Garda A.A. 2014. A new species of Pseudopaludicola (Anura: Leptodactylidae: Leiuperinae) from northeastern Brazil. Herpetologica 70: 77-88. https://doi.org/10.1655/HERPETOLOGICA-D-13-00054

Maniatis T., Fritsch E.F. \& Sambrook J. 1982. Molecular Cloning: a Laboratory Manual. Cold Spring Harbor Laboratory, New York.

Miller M.A., Pfeiffer W. \& Schwartz T. 2010. Creating the CIPRES Science Gateway for Inference of Large Phylogenetic Trees. Proceedings of the Gateway Computing Environments Workshop (GCE), New Orleans. https://doi.org/10.1109/GCE.2010.5676129

Miranda-Ribeiro A. 1937. Alguns batrachios novos das colleções do Museo Nacional. O Campo 8: $66-69$.

Myers N., Mittermeier R.A., Mittermeier C.G., da Fonseca G.A.B. \& Kent J. 2000. Biodiversity hotspots for conservation priorities. Nature 403: 853-858. https://doi.org/10.1038/35002501

Neves M.O., Yves A., Pereira E.A., Alves L., Vasques J.B., Coelho J.F.T. \& Silva P.S. 2019. Herpetofauna in a highly endangered area: the Triângulo Mineiro region, in Minas Gerais State, Brazil. Herpetozoa 32: 113-123. https://doi.org/10.3897/herpetozoa.32.e35641

Oliveira E.A., Hernández-Ruz E.J., de Carvalho J.C. \& Sanches D. 2013. Geographic distribution: Pseudopaludicola canga. Herpetological Review 44: 104.

Oliveira S.R., Santos C.E., Souza A.O., Lima-Ribeiro M.S., Vergilio K., Zórtea M., Silva D.A., Melo F.R., Guilherme F.A.G., Vaz-Silva W. \& Morais A.R. 2019. Species composition and reproductive modes of anurans from the southwestern state of Goiás, Brazil. Herpetology Notes 12: 491-499.

Pansonato A., Morais D.H., Ávila R.W., Kawashita-Ribeiro R.A., Strüssmann C. \& Martins I.A. 2012. A new species of Pseudopaludicola Miranda-Ribeiro, 1926 (Anura: Leiuperidae) from the state of Mato 
ANDRADE F.S. et al., Taxonomic status of P. parnaiba and a new congeneric species

Grosso, Brazil, with comments on the geographic distribution of Pseudopaludicola canga Giaretta \& Kokubum, 2003. Zootaxa 3523: 49-58. https://doi.org/10.11646/zootaxa.3523.1.5

Pansonato A., Strüssmann C., Mudrek J.R. \& Martins I.A. 2013. Morphometric and bioacoustic data on three species of Pseudopaludicola Miranda-Ribeiro, 1926 (Anura: Leptodactylidae: Leiuperinae) described from Chapada dos Guimarães, Mato Grosso, Brazil, with the revalidation of Pseudopaludicola ameghini (Cope, 1887). Zootaxa 3620: 147-162. https://doi.org/10.11646/zootaxa.3620.1.7

Pansonato A., Mudrek J.R., Veiga-Menoncello A.C.P., Rossa-Feres D.C., Martins I.A. \& Strüssmann C. 2014a. Anew species of Pseudopaludicola Miranda-Ribeiro, 1926 (Anura: Leptodactylidae: Leiuperinae) from northwestern state of São Paulo, Brazil. Zootaxa 3861: 249-264.

https://doi.org/10.11646/zootaxa.3861.3.3

Pansonato A., Mudrek J.R., Simioni F., Martins I.A. \& Strüssmann C. 2014b. Geographical variation in morphological and bioacoustic traits of Pseudopaludicola mystacalis (Cope, 1887) and a reassessment of the taxonomic status of Pseudopaludicola serrana Toledo, 2010 (Anura: Leptodactylidae: Leiuperinae). Advances in Zoology 2014: 1-13. https://doi.org/10.1155/2014/563165

Pansonato A., Veiga-Menoncello A.C.P., Mudrek J.R., Jasen M., Recco-Pimentel S.M., Martins I.A. \& Strüssmann C. 2016. Two new species of Pseudopaludicola (Anura: Leptodactylidae: Leiuperinae) from eastern Bolivia and western Brazil. Herpetologica 72: 235-255.

https://doi.org/10.1655/Herpetologica-D-14-00047.1

Pereira E.G. \& Nascimento L.B. 2004. Descrição da vocalização e do girino de Pseudopaludicola mineira Lobo, 1994, com notas sobre a morfologia de adultos (Amphibia, Anura, Leptodactylidae). Arquivos do Museu nacional 62: 233-240.

R Core Team 2019. R: A Language and Environment for Statistical Computing. ver. 3.5.3. R Foundation for Statistical Computing, Vienna, Austria. Available from http://www.R-project.org/ [accessed 1 Jan. 2019].

Ramalho W.P., França D.P.F., Guerra V., Marciano R., Vale N.C. \& Silva H.L.R. 2018. Herpetofauna of Parque Estadual Altamiro de Moura Pacheco: one of the last remnants of seasonal forest in the core region of the Brazilian Cerrado. Papéis Avulsos de Zoologia 58: e20185851.

http://doi.org/10.11606/1807-0205/2018.58.51

Rivero J.A. \& Serna M.A. 1985. Una nueva Pseudopaludicola (Amphibia: Leptodactylidae) cornuda del sureste de Colombia. Caribbean Journal of Science 20:169-171.

Roberto I.J., Cardozo D. \& Ávila R.W. 2013. A new species of Pseudopaludicola (Anura, Leiuperidae) from western Piauí State, Northeast Brazil. Zootaxa 3636: 348-360.

https://doi.org/10.11646/zootaxa.3636.2.6

Ruthven A.G. 1916. A new species of Paludicola from Colombia. Occasional Papers of the Museum of Zoology, University of Michigan 30: 1-3.

Stamatakis, A. 2014. RAxML version 8: a tool for phylogenetic analysis and post-analysis of large phylogenies. Bioinformatics 30: 1312-1313. https://doi.org/10.1093/bioinformatics/btu033

Strassburg B.B.N., Brooks T., Feltran-Barbieri R., Iribarrem A., Crouzeilles R., Loyola R., Latawiec A.E., Filho F.J.B.O., Scaramuzza C.A.M., Scarano F.R., Soares-Filho B. \& Balmford A. 2017. Moment of truth for the Cerrado hotspot. Nature Ecology \& Evolution 1: 0099.

https://doi.org/10.1038/s41559-017-0099

Sueur J., Aubin T. \& Simonis C. 2008. Seewave, a free modular tool for sound analysis and synthesis. Bioacoustics 18: 213-226. https://doi.org/10.1080/09524622.2008.9753600 
Taylor W.R. \& Van Dyke G.C. 1985. Revised procedures for staining and clearing small fishes and other vertebrates for bone and cartilage study. Cybium IX (2): 107-119.

Toledo L.F., Siqueira S., Duarte T.C., Veiga-Menoncello A.C.P., Recco-Pimentel S.M. \& Haddad C.F.B. 2010. Description of a new species of Pseudopaludicola Miranda-Ribeiro, 1926 from the State of São Paulo, Southeastern Brazil (Anura, Leiuperidae). Zootaxa 2496: 38-480.

https://doi.org/10.11646/zootaxa.2496.1.2

Vaidya G., Lohman D.J. \& Meier R. 2011. SequenceMatrix: concatenation software for the fast assembly of multi-gene datasets with character set and codon information. Cladistics 27: 171-180.

https://doi.org/10.1111/j.1096-0031.2010.00329.x

Valdujo P.H., Carnaval A.C.O.Q. \& Graham C. 2013. Environmental correlates of anuran beta diversity in the Brazilian Cerrado. Ecography 35: 1-10. https://doi.org/10.1111/j.1600-0587.2012.07374.x

Vaz-Silva W. \& Maciel N.M. 2011. A new cryptic species of Ameerega (Anura: Dendrobatidae) from Brazilian Cerrado. Zootaxa 2826: 57-68. https://doi.org/10.11646/zootaxa.2826.1.3

Veiga-Menoncello A.C.P., Lourenço L.B., Strüssmann C., Rossa-Feres D.C., Andrade G.V., Giaretta A.A. \& Recco-Pimentel S.M. 2014. A phylogenetic analysis of Pseudopaludicola (Anura) providing evidence of progressive chromosome reduction. Zoologica Scripta 43: 261-272.

https://doi.org/10.1111/zsc. 12048

Walker M., Lyra M.L. \& Haddad C.F.B. 2018. Phylogenetic relationships and cryptic species diversity in the Brazilian Egg-Brooding tree frog, genus Fritziana Mello-Leitão 1937 (Anura: Hemiphractidae). Molecular Phylogenetic and Evolution 123: 59-72. https://doi.org/10.1016/j.ympev.2018.02.012

Watters J.L., Cummings S.T., Flanagan R.L. \& Siler C.D. 2016. Review of morphometric measurements used in anuran species descriptions and recommendations for a standardized approach. Zootaxa 4072 (4): 477-495. http://doi.org/10.11646/zootaxa.4072.4.6

Manuscript received: 30 January 2020

Manuscript accepted: 11 May 2020

Published on: 3 July 2020

Topic editor: Rudy C.A.M. Jocqué

Desk editor: Radka Rosenbaumová

Printed versions of all papers are also deposited in the libraries of the institutes that are members of the EJT consortium: Muséum national d'histoire naturelle, Paris, France; Meise Botanic Garden, Belgium; Royal Museum for Central Africa, Tervuren, Belgium; Royal Belgian Institute of Natural Sciences, Brussels, Belgium; Natural History Museum of Denmark, Copenhagen, Denmark; Naturalis Biodiversity Center, Leiden, the Netherlands; Museo Nacional de Ciencias Naturales-CSIC, Madrid, Spain; Real Jardín Botánico de Madrid CSIC, Spain; Zoological Research Museum Alexander Koenig, Bonn, Germany; National Museum, Prague, Czech Republic. 
Appendix 1. Specimens examined.

Pseudopaludicola ameghini

BRAZIL - Mato Grosso • Chapada dos Guimarães (type locality); ZUEC 14138, 14139, 14141 to 14145.

Pseudopaludicola atragula

BRAZIL - São Paulo • Icém (type locality); AAG-UFU 5103 to 5105, 5107, 5109.

Pseudopaludicola boliviana

ARGENTINA - Chaco Province • Antequera; MNRJ 75298. - Corrientes Province • Itá-Ibaté; MNRJ 75299. - Santa Fé Province • General Obligado; MNRJ 75300. - Formosa Province • Tres Marias; MNRJ 75301 • Riacho Formosa; MNRJ 75303 • Tatané; MNRJ 75304 to 75308 • Virasol; MNRJ 75309 to $75312 \cdot$ Colonia Salvación; MNRJ 75322.

Pseudopaludicola canga

BRAZIL - Pará • Marabá, Serra dos Carajás (type locality); ZUEC 9990, 10034, 14370, 14372 to 14374, 14378. - Maranhão • Barreirinhas; ZUEC 24687 to 24695 • Santo Amaro do Maranhão; ZUEC 24682 to 24686.

Pseudopaludicola coracoralinae sp. nov.

BRAZIL - Goiás • Palmeiras de Goiás (type locality); ZUEC 24701 to 24712 • Same collection data as for preceding; AAG-UFU 3393 to 3396.

Pseudopaludicola facureae

BRAZIL - Minas Gerais • Uberlândia (type locality); AAG-UFU 0853 to 0855 • Same collection data as for preceding; ZUEC 13651, 13652, 14215, 14218, 14219, 14221, 14224.

Pseudopaludicola falcipes

BRAZIL - Rio Grande do Sul • Eldorado do Sul; ZUEC 11468 • Novo Hamburgo; ZUEC 4876 • Porto Alegre; ZUEC 10387, 10388, 13999, 13000, 14002, 14003, 14005, 14006, 14008, 14009, 14016, 14017 , 14022, 14162 to 14166,14168 - Santana do Livramento; ZUEC 10355, 10356 • Viamão; ZUEC 5297 to 5299 .

Pseudopaludicola florencei

BRAZIL - Bahia - Andaraí (type locality); ZUEC 23512 to 23530 - Same collection data as for preceding; UFMG 4310 to 4316.

Pseudopaludicola giarettai

BRAZIL - Minas Gerais • Curvelo (type locality); AAG-UFU 0309 to 0317 • Same collection data as for preceding; ZUEC 24319 to 24322.

Pseudopaludicola jaredi

BRAZIL - Ceará • Viçosa do Ceará (type locality); CFBH 32609, 32614, 32617 to 32625 - Same collection data as for preceding; ZUEC 20477 to 20484 • Nísia Floresta; ZUEC 21858 to 21872. 
Pseudopaludicola jazmynmcdonaldae

BRAZIL - Tocantins • Caseara (type locality); ZUFMS-AMP 11247 to 11258 • Same collection data as for preceding; ZUEC 24457 to 24464.

Pseudopaludicola matuta

BRAZIL - Minas Gerais - Curvelo (type locality); ZUEC 24302 to 24306, 24308 to 24310, 24313, 24315 to 24318.

Pseudopaludicola mineira

BRAZIL - Minas Gerais - Jaboticatubas (Serra do Cipó, type locality); ZUEC 1570, 1572 to 1589, 1591.

Pseudopaludicola murundu

BRAZIL - São Paulo • Águas de Santa Bárbara; ZUEC 20507, 20508 - Rio Claro (type locality); AAG-UFU 5125, 5126, CFBH 8235 to 8242 - Same collection data as for preceding; ZUEC 14284 to 14290. - Minas Gerais • Brumadinho; ZUEC 16396 to 16398, 16442, 16443, 19549, 19551, 19555, 19557 to 19578,19560 - Santana do Riacho; ZUEC 2323 - São João del-Rei; ZUEC 16447 to 16452 , $16455,16456$.

Pseudopaludicola mystacalis

BRAZIL - Goiás • Itapirapuã; ZUEC 10222. - Mato Grosso • Cáceres; ZUEC 10286 • Chapada dos Guimarães (type locality); ZUEC 5115, 5117, 5119, 5121, 10685. - Mato Grosso do Sul • Três Lagoas; ZUEC 16720, 16949. - Tocantins • Formoso do Araguaia; ZUEC 10154.

Pseudopaludicola parnaiba (junior synonym of $P$. canga)

BRAZIL - Piauí • Ribeiro Gonçalves (type locality); ZUEC 24673 to 24680.

Pseudopaludicola pocoto

BRAZIL - Ceará • Novas Russas; CFBH 20285 to 20287 • Santa Quitéria (type locality); CFBH 26842 to 26847. - Bahia - Rio de Contas; ZUEC 25506 to 25510 - Same collection data as for preceding; UFMG 5902 to 5911.

Pseudopaludicola saltica

BRAZIL - Mato Grosso - Chapada dos Guimarães (type locality); ZUEC 14228, 14230 to 14233, 14235, 14239, 14240, 14244, 14247, 14272, 5134 to 51346, 5854, 5855. - Minas Gerais • Uberlândia; AAG-UFU 2308, 2630, 4598, 4631, 4735, 4707 to 4711.

Pseudopaludicola ternetzi

BRAZIL - Goiás • Uruaçu (type locality); MNRJ 445 to 447, 5460 to 5462, 5442. - Minas Gerais • Uberlândia; ZUEC 14036 to 14039, 14170, 14171. - Tocantins • Formoso do Araguaia; ZUEC 10140 to $10143,10145,10147,10150,10153$. 


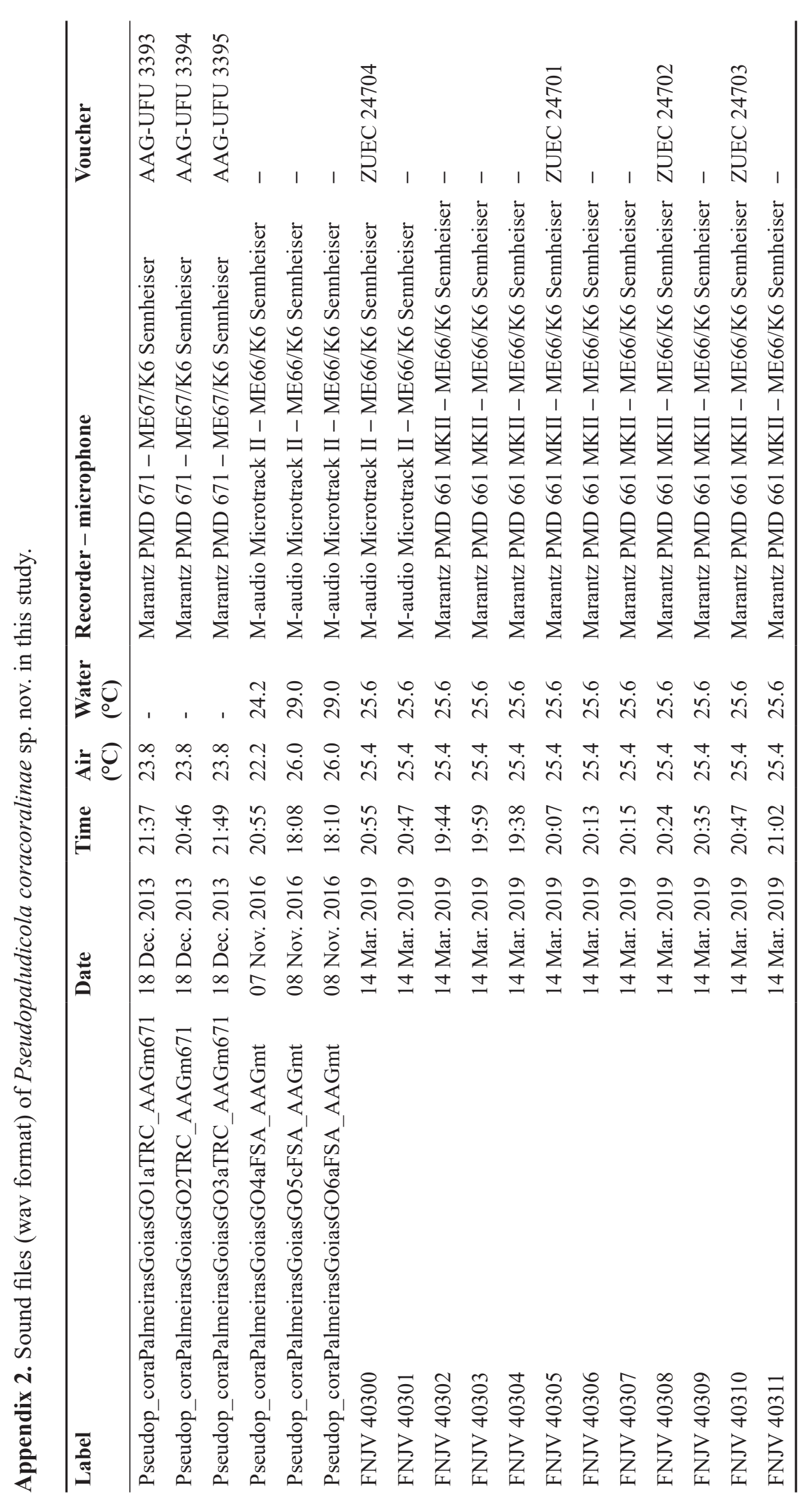


Appendix 3 (continued on next two pages). Specimens of Pseudopaludicola Miranda-Ribeiro, 1926 used for phylogenetic inferences with voucher number, sample locality and GenBank accession number. The sequences provided for the present study are in bold. Outgroups are also listed.

\begin{tabular}{|c|c|c|c|}
\hline Species & Voucher/tissue & Locality & $\begin{array}{l}\text { 12S-tval-16S/ } \\
{[12 S, 16 S]}\end{array}$ \\
\hline P. ameghini & ZUEC 14140 & Chapada dos Guimarães, MT, type locality & KJ146975 \\
\hline P. ameghini & UFMT 8543 & Chapada dos Guimarães, MT, type locality & KJ146976 \\
\hline P. atragula & DZSJRP 8727 & Icém, SP, type locality & KJ146996 \\
\hline P. atragula & DZSJRP 8728 & Icém, SP, type locality & KJ146997 \\
\hline P. canga & ZUEC 14333 & Serra dos Carajás, PA, type locality & KJ146988 \\
\hline P. canga & ZUEC 14334 & Serra dos Carajás, PA, type locality & KJ146989 \\
\hline P. canga & ZUEC 14335 & Serra dos Carajás, PA, type locality & KJ146990 \\
\hline P. canga & AAG-UFU 6266 & Aragominas, TO & MT385236 \\
\hline P. canga & AAG-UFU 6267 & Aragominas, TO & MT385237 \\
\hline P. canga & AAG-UFU 2745 & Palmas, TO & MT385238 \\
\hline P. canga & AAG-UFU 2746 & Palmas, TO & MT385239 \\
\hline P. canga & AAG-UFU 2527 & Mateiros, GO & MT385240 \\
\hline P. coracoralinae & AAG-UFU 3393 & Palmeiras de Goiás, GO, type locality & MT385241 \\
\hline P. coracoralinae & AAG-UFU 3394 & Palmeiras de Goiás, GO, type locality & MT385242 \\
\hline P. coracoralinae & ZUEC 24702 & Palmeiras de Goiás, GO, type locality & MT385243 \\
\hline P. coracoralinae & ZUEC 24703 & Palmeiras de Goiás, GO, type locality & MT385244 \\
\hline P. coracoralinae & $\begin{array}{l}\text { ZUEC 24704 } \\
\text { (holotype) }\end{array}$ & Palmeiras de Goiás, GO, type locality & MT385245 \\
\hline P. facureae & ZUEC 14173 & Uberlândia, MG, type locality & KJ146978 \\
\hline P. facureae & ZUEC 14174 & Uberlândia, MG, type locality & KJ146979 \\
\hline P. facureae & ZUEC 14175 & Uberlândia, MG, type locality & KJ146980 \\
\hline P. giarettai & AAG-UFU 1920 & Grande Sertão Veredas National Park, MG & MH553445 \\
\hline P. giarettai & AAG-UFU 1921 & Grande Sertão Veredas National Park, MG & MH553444 \\
\hline P. giarettai & ZUEC 24319 & Curvelo, MG, type locality & MH553442 \\
\hline P. giarettai & ZUEC 24320 & Curvelo, MG, type locality & MH553443 \\
\hline P. jazmynmcdonaldae & ZUFMS 11249 & Caseara, TO, type locality & MT385246 \\
\hline P. jazmynmcdonaldae & ZUFMS 11252 & Caseara, TO, type locality & MT385247 \\
\hline P. jazmynmcdonaldae & ZUFMS 11256 & Caseara, TO, type locality & MT385248 \\
\hline P. jazmynmcdonaldae & ZUFMS 11257 & Caseara, TO, type locality & MT385249 \\
\hline P. mystacalis & CFBH 35858 & Urbano Santos, MA & KJ146982 \\
\hline P. mystacalis & ZUEC 14147 & Cuiabá, MT & KJ146983 \\
\hline P. mystacalis & ZUEC 14160 & Poconé, MT & KJ146991 \\
\hline P. mystacalis & ZUEC 14128 & Uberlândia, MG & KJ146999 \\
\hline P. mystacalis & ZUEC 13836 & Barreirinhas, MA & KJ147005 \\
\hline P. mystacalis & CFBH-T 1374 & Paranaíba, MS & KJ147009 \\
\hline P. mystacalis & DZSJRP 8704 & Santa Fé do Sul, SP & KJ147022 \\
\hline P. mystacalis & DZSJRP 8724 & Icém, SP & KJ147028 \\
\hline P. mystacalis & CFBH-T 03509 & Babaçulândia, TO & KU495493 \\
\hline P. canga & ZUEC 13858 & Barreirinhas, MA & KJ147013 \\
\hline
\end{tabular}


ANDRADE F.S. et al., Taxonomic status of P. parnaiba and a new congeneric species

Appendix 3 (continued). Specimens of Pseudopaludicola Miranda-Ribeiro, 1926 used for phylogenetic inferences with voucher number, sample locality and GenBank accession number. The sequences provided for the present study are in bold. Outgroups are also listed.

\begin{tabular}{|c|c|c|c|}
\hline Species & Voucher/tissue & Locality & $\begin{array}{l}\text { 12S-tval-16S/ } \\
{[12 S, 16 S]}\end{array}$ \\
\hline P. canga & ZUEC 13859 & Barreirinhas, MA & KJ147014 \\
\hline P. canga & ZUEC 13860 & Barreirinhas, MA & KJ147015 \\
\hline $\begin{array}{l}\text { P. canga (topotype of } \\
\text { P. parnaiba) }\end{array}$ & ZUEC 24676 & Ribeiro Gonçalves, PI, type locality & MT385250 \\
\hline $\begin{array}{l}\text { P. canga (topotype of } \\
\text { P. parnaiba) }\end{array}$ & ZUEC 24677 & Ribeiro Gonçalves, PI, type locality & MT385251 \\
\hline $\begin{array}{l}\text { P. canga (topotype of } \\
\text { P. parnaiba) }\end{array}$ & ZUEC 24678 & Ribeiro Gonçalves, PI, type locality & MT385252 \\
\hline P. canga & ZUEC 24682 & Santo Amaro do Maranhão, MA & MT385253 \\
\hline P. canga & ZUEC 24683 & Santo Amaro do Maranhão, MA & MT385254 \\
\hline P. canga & ZUEC 24687 & Barreirinhas, MA & MT385255 \\
\hline P. canga & ZUEC 24688 & Barreirinhas, MA & MT385256 \\
\hline P. ternetzi & UFMT 15753 & Uruaçu, GO, type locality & KJ147054 \\
\hline P. ternetzi & UFMT 15754 & Uruaçu, GO, type locality & KJ147055 \\
\hline P. falcipes & MACN 38647 & Yapeyu, Corrientes, Argentina & AY843741 \\
\hline P. falcipes & ZUEC 14162 & Porto Alegre, RS & KJ146972 \\
\hline P. florencei & ZUEC 14190 & Andaraí, BA, type locality & KJ147017 \\
\hline P. florencei & ZUEC 14189 & Andaraí, BA, type locality & KJ147018 \\
\hline P. jaredi & SMRP 310.18 & Viçosa do Ceará, CE, type locality & KJ147033 \\
\hline P. jaredi & SMRP 310.19 & Viçosa do Ceará, CE, type locality & KJ147034 \\
\hline P. murundu & CFBH-T 1467 & Rio Claro, SP, type locality & KJ147008 \\
\hline P. murundu & ZUEC 14288 & Rio Claro, SP, type locality & KJ147030 \\
\hline P. mineira & DZSJRP 6437 & Serra do Cipó, MG, type locality & KJ147025 \\
\hline P. mineira & ZUEC 14318 & Serra do Cipó, MG, type locality & KJ147026 \\
\hline P. matuta & ZUEC 24303 & Curvelo, MG, type locality & MH553454 \\
\hline P. matuta & ZUEC 24304 & Curvelo, MG, type locality & MH553456 \\
\hline P. pocoto & SMRP 440.1 & Novas Russas, CE & KJ147035 \\
\hline P. pocoto & SMRP 440.2 & Novas Russas, CE & KJ147036 \\
\hline P. restinga & ZUEC 24583 & Serra, ES, type locality & MT385257 \\
\hline P. restinga & ZUEC 24584 & Serra, ES, type locality & MT385258 \\
\hline P. saltica & ZUEC 14239 & Chapada dos Guimarães, MT, type locality & KJ147002 \\
\hline P. saltica & ZUEC 14240 & Chapada dos Guimarães, MT, type locality & KJ147003 \\
\hline P. boliviana & MLP-DB 5186 & Corrientes, Argentina & KJ147049 \\
\hline P. boliviana & MLP-DB 5614 & Chaco, Argentina & KJ147050 \\
\hline P. llanera & ANDES-A 1253 & Sabanalarga, Casanare, Colombia & KP149482 \\
\hline P. llanera & ANDES-A 1114 & Sabanalarga, Casanare, Colombia & KP149483 \\
\hline P. motorzinho & ZUEC 13928 & Poconé, MT & KJ146992 \\
\hline P. motorzinho & ZUEC 13931 & Poconé, MT & KJ147039 \\
\hline P. pusilla & ANDES-A 1791 & San Vicente, Santander, Colombia & KP149486 \\
\hline
\end{tabular}


Appendix 3 (continued). Specimens of Pseudopaludicola Miranda-Ribeiro, 1926 used for phylogenetic inferences with voucher number, sample locality and GenBank accession number. The sequences provided for the present study are in bold. Outgroups are also listed.

\begin{tabular}{llll}
\hline Species & Voucher/tissue & Locality & 12S-tval-16S/ \\
& & [12S, 16S] \\
\hline P. pusilla & ANDES-A 1790 & San Vicente, Santander, Colombia & KP149344 \\
Alsodes gargola & outgroup & & AY843565 \\
Allophryne ruthveni & outgroup & & AY843564 \\
Adenomera hylaedactyla & outgroup & DQ283063 \\
Crossodactylodes & outgroup & KC593358 \\
bokermanni & & \\
Edalorhina perezi & outgroup & AY883585 \\
Engystomops petersi & outgroup & FJ668193 \\
Hydrolaetare caparu & outgroup & KC603953, \\
& & KC603954 \\
Leptodactylus latrans & outgroup & AY843688 \\
Leptodactylus pentadactylus & outgroup & AY326017 \\
Lithodytes lineatus & outgroup & AY843690 \\
Odontophrynus americanus & outgroup & AY843704 \\
Paratelmatobius gaigeae & outgroup & EU224397 \\
Physalaemus cuvieri & outgroup & AY843729 \\
Physalaemus nattereri & outgroup & DQ337208 \\
Pleurodema brachyops & outgroup & AY843733 \\
Proceratophrys avelinoi & outgroup & KP295643 \\
Rupirana cardosoi & outgroup & KC593361 \\
Scythrophrys sawayae & outgroup & DQ283099 \\
Vitreorana eurygnatha & outgroup & AY843595 \\
\hline
\end{tabular}


ANDRADE F.S. et al., Taxonomic status of P. parnaiba and a new congeneric species

Appendix 4. Primers used to amplify the mitochondrial fragments 12S, tRNA-val, 16S.

\begin{tabular}{lll}
\hline Name & Sequence (5'-3') & Author \\
\hline MVZ59 & ATAGCACGTAAAAYGCTDAGATG & Graybeal 1997 \\
tRNA-Val & GGTGTAAGCGARAGGCTTTKGTTAAG & Goebel et al. 1999 \\
12S-L13 & TTAGAAGAGGCAAGTCGTAACATGGTA & Feller \& Hedges 1998 \\
16S-H10 & TGCTTACGCTACCTTTGCACGGT & Hedges 1994 \\
16Sa-L & CGCCTGTTTATCAAAAACAT & Palumbi et al. 1991 \\
16Sb-H & CCCGTCTGAACTCAGATCACGT & Palumbi et al. 1991 \\
\hline
\end{tabular}

Graybeal A. 1997. Phylogenetic relationships of bufonid frogs and tests of alternate macroevolutionary hypothesis characterizing their radiation. Zoological Journal of the Linnean Society 119: 297-338. https://doi.org/10.1111/j.1096-3642.1997.tb00139.x

Goebel A.M., Donnelly J.M. \& Atz M.E. 1999. PCR primers and amplification methods for 12S ribosomal DNA, the control region, cytochrome oxidase I, and cytochrome $\mathrm{b}$ in bufonids and other frogs, and an overview of PCR primers which have amplified DNA in amphib- ians successfully. Molecular Phylogenetics and Evolution 11: 163-199. https://doi.org/10.1006/mpev.1998.0538

Feller A.E. \& Hedges S.B. 1998. Molecular evidence for the early history of living amphibians. Molecular Phylogenetics and Evolution 9: 509-516. https://doi.org/10.1006/mpev.1998.0500

Hedges S.B. 1994. Molecular evidence for the origin of birds. Proceedings of the Natural Academy of Science 91: 2621-2624. https://doi.org/10.1073/pnas.91.7.2621

Palumbi S.R., Martins A., Romano S., McMillan W.O., Stice L. \& Grabawski G. 1991. The Simple Fool'S Guide to PCR, ver. 2.0. University of Hawaii, Honolulu. Privately published, compiled by S. Palumbi. 


\section{Supplementary material}

Supplementary file 1 . Acoustic terminology employed.

Supplementary file 2. Estimates of evolutionary divergence between sequences of the species from Pseudopaludicola canga clade.

Supplementary file 3. Phylogenetic relationships of the Pseudopaludicola species based on the $12 \mathrm{~S}$ rRNA, tRNA-val and 16S rRNA mitochondrial genes fragment, including the 19 outgroups. Numbers near the nodes are the support values from a maximum likelihood bootstrap analysis. Black dots represent bootstrap $=100$; support below species level is not shown. 